\title{
A New Examination of the Impacts of Regional Trade Agreements on International Trade Patterns
}

\author{
Duc Bao Nguyen ${ }^{1+}$ \\ ${ }^{1}$ GREThA, UMR CNRS 5113, University of Bordeaux, Bordeaux, France
}

\begin{abstract}
This paper assesses the ex-post effects on the international trading system of eighteen pluri-lateral regional trade agreements (RTAs) by examining their impacts on intra-bloc trade and on the tendency of members to trade with the rest of the world. This study is based on a gravity model with a solid theoretical foundation involving Anderson and van Wincoop's (2003) multilateral resistance terms. The model assesses 160 countries over a time period that extends from 1960 to 2014. Making use of the Poisson pseudo maximum likelihood (PPML) estimator and selecting the proper RTA variable and fixed effects settings, our analysis confirms the widespread trade-promoting effects of RTAs with mixed effects on extra-bloc trade. However, trade diversion in terms of bloc exports and imports are detected mostly in American and African trade agreements in many cases. By contrast, export and import creations are more prominent for RTAs in Europe and Asia.
\end{abstract}

Keywords: Gravity model, Regional trade agreements, Regional integration, Trade creation, Trade diversion JEL Classifications: F11, F13, F15

Received 15 April 2019, Revised 29 April 2019, Accepted 30 April 2019

\section{Introduction}

Regional trade agreements (RTAs) have rapidly proliferated around the world in recent years. As of January 2019, there are 291 RTAs currently in force that have been reported to the World Trade Organization (WTO) (WTO 2019). This type of trade agreement has become a key component of trade policy for many countries around the globe. Balassa (1961) summarized the various forms of integration for RTAs, such as free trade areas, customs unions, common markets, economic unions and total economic integration. The form of RTAs is based on the different degrees of suppression of discrimination resulting from trade barriers and national economic programs among the member countries.

\section{+Comesponding Author: Duc Bao Nguyen}

Ph.D candidate, GREThA, UMR CNRS 5113, University of Bordeaux, 33608 Pessac Cedex, France, Tel: +33 556842575, Email: duc-bao.nguyen@u-bordeaux.fr

Acknowledgements: The author would like to thank Antoine Bouët, Anne-Gaël Vaubourg, and participants at the 19th INFER Annual Conference (Bordeaux 2017) and the 8th Doctoriades Workshop (Toulon 2017) for useful suggestions and comments. The author also thanks the editors and two anonymous referees for their valuable comments and suggestions to improve this paper. Any errors or omissions are solely the responsibility of the author. 
RTAs have always been accompanied by a multilateral trading system. However, there has been debate on the relationship between regionalism and multilateralism since the early 1990s. The Uruguay Round overcame many challenges in its negotiations before finally being signed in 1994, and the number of RTAs entering into force has steadily increased since 1995, following the establishment of the WTO1). Several scholars consider the proliferation of RTAs to be a major challenge to the multilateral trade process. Bhagwati (1991) indicated that regionalism embodies a discriminatory characteristic and could induce perverse effects. A steady increase in RTAs could also be detrimental to non-members or the rest of the world (Baldwin 1993). According to Bhagwati (1995), within regional groups, the countries with greater power gain from trade liberalization, while smaller countries lose from trade liberalization. The author also argues that regionalism could increase the risk of conflicts between regional trading blocs.

Conversely, others perceive a regional trading system as a step toward the breakthrough of multilateral trade liberalization under the umbrella of the WTO. Summers (1991) argues that regional trade liberalization generates an advance on multilateralism and leads to more trade creation than trade diversion. Thus, the inclination toward regional trade integration did not hinder the achievement of the Uruguay Round negotiations because the countries driving the multilateral trade system after the Second World War were the same nations that promoted regional trade liberalization (Baldwin 2004). Moreover, RTAs can also encourage foreign direct investment (Lawrence 1996, Kimura and Ando 2005, Freund and Ornelas 2010) and economic growth in member countries through technological transfer.

The upsurge in RTAs throughout the world over the past two decades has resulted in the emergence of a dense, complex network of RTAs, in which there are several overlapping agreements among the same trading partners. In the context of the multilateral trading system, RTAs operate under rules introduced by the WTO. It may seem that RTAs violate one of the most important pillars of the WTO, the most-favored-nation (MFN) principle, which prohibits countries from discriminating between their trading partners ${ }^{2}$. However, RTAs are considered to be an exception to MFN obligations. In fact, the WTO rules lay down a legal framework for RTAs covering the trade of goods in Article XXIV (GATT 1994) and paragraph 2(c) of the Enabling Clause (GATT 1979). In this study, we focus on the term "regional trade agreements" used under the GATT/WTO rules, which takes into account agreements covering the liberalization of the goods trade, i.e., free trade areas and customs unions 3 ).

In the context of the growing trend toward regionalism, owing to the steady increase in

1) Acharya (2016) found that approximately three RTAs on average were notified per year during the General Agreement on Tariffs and Trade (GATT) period (from 1948 to 1994) compared with the WTO period (since 1995), when, on average, twenty-five RTAs have been notified per year.

2) The MFN requires that any trade advantages one country grants to another member must also be offered to all other WTO members.

3) These two terms are adopted in Article XXIV (GATT 1994). 
the number of RTAs established globally since the early 1990s, this paper will revisit the ex-post effects of RTAs on the multilateral trading system over a long time span, i.e., the period from 1960 until 2014. This period covers nearly all of the waves of regionalism worldwide since the Second World War.

The motivation for this study comes first from the recent upsurge in the number of regional trade agreements and of cross-regional trade agreements, which involve countries that are geographically distant from each other. Additionally, bilateral agreements have been prioritized with regard to plurilateral RTAs because it is likely to be more difficult to accomplish a trade deal among a broad group of trading partners with diverging economic and political interests (Bhagwati 2008). Therefore, we are keen to take a fresh look at the following questions: Does regional integration by means of plurilateral RTAs truly increase the members' trade? What are their impacts on the rest of the world?

Keeping this in mind, our choice of trading blocs in this analysis comes from the "pure" form of regionalism, which embraces trading blocs formed by countries in a common geographic area or within close proximity. We aim to study the impacts of most plurilateral RTAs on their intra-bloc trade and the tendencies of member countries to trade with the rest of the world in the wake of their formation. We, thus explore whether the regional trading blocs around the world have stimulated trade among members as well as trade with non-members or, in an alternate scenario, if they have increased members' trade to the detriment of non-members.

Second, researchers have renewed their interest in the application of the gravity model to analyze bilateral trade flows, especially after the emergence of its more solid theoretical foundation in the early 2000s. Over the past fifty years, the gravity equation has become the most fruitful and dominant empirical framework for analyzing international trade. The basic gravity model, which was introduced by Tinbergen (1962), found that the bilateral trade flows between two trading partners depended on their countries' incomes positively and bilateral distance negatively. However, this model, which is inspired by Newton's law of gravity, did not have solid underpinnings in economic theory. Several authors have attempted to develop strong theoretical foundations for the gravity model since the late 1970s ${ }^{4}$ ). Much improvement has been achieved; more recently and more notably, Anderson and van Wincoop (2003) laid out and popularized a solid theoretical framework of the gravity equation that takes into account multilateral resistance terms, as also introduced by the two authors.

Third, questions have also been raised in the empirical literature regarding the appropriate formulation of variables in the gravity equation, mostly regarding the dummy variables that are used to assess the impacts of RTAs. There has been a revolution in the choice of dummy variables for better examination of the trade effects associated with RTAs in terms of trade

4) See Anderson (1979), Helpman and Krugman (1985), Bergstrand (1989), Deardorff (1998), Baier and Bergstrand (2001). 
creation and trade diversion introduced by Viner (1950). Based on a static and partial equilibrium framework, Viner (1950) argued that an RTA did not necessarily enhance the member countries' welfare. The author found that RTAs under the form of free trade areas or customs unions are likely to produce trade creation if the member countries import more from efficient producers located in other member countries at the expense of less efficient producers in the domestic market. Accordingly, RTAs enhance efficiency from both sides concerning production and consumption and increase the welfare for member countries. By contrast, RTAs may lead to trade diversion when the members discontinue importing from the most efficient suppliers (low-cost producers) in the rest of the world and import instead from inefficient suppliers (higher-cost producers) in other member countries. This situation leads to inefficiency in global production, which is detrimental to the outsiders of RTAs. It can also be harmful to member countries when the consumer surplus does not outweigh the cost of the inefficiency in production.

The net effect of trade liberalization following the formation of an RTA is ambiguous and depends on whether a trade creation effect or the trade diversion effect is dominant5). Although Viner's findings only focus on the static impacts of RTAs and do not clearly address their net welfare effects, his two principal concepts of trade creation and trade diversion have significantly inspired later theoretical and empirical studies on the effects of RTAs6). Since then, the results from the empirical literature have remained quite mixed. In this paper, we adopt the method that includes three dummy variables for each RTA to adequately capture the Vinerian trade effects. These dummy variables will explain the impacts of each RTA on intra-bloc trade, members' imports, and members' exports to the rest of the world.

Fourth, we are also motivated by the drawback shown in a large stream of literature involving specific studies in which the impacts of one or a few individual RTAs are examined. Since these studies only focus on a specific RTA or a small group of RTAs, they usually examine one geographic region and employ a small sample of countries and a short time span. Moreover, each of the studies following this specialist approach applies a different econometric strategy and does not take into account improvements in the estimation techniques. Although these specific studies could provide interesting insights on the effects of a specific agreement, they do not have enough generalizability in their findings. It is extremely challenging to compare the results of RTAs across specific studies. Hence, this analysis will assess the trade impacts

5) Viner (1950, p.44) states that: "Where the trade-creating force is predominant, one of the members at least must benefit, both may benefit, two combined must have a net benefit, and the world at large benefits; but the outside world loses, in the short-run at least... Where the trade-diverting effect is predominant, one at least of the member countries is bound to be injured, both may be injured, the two combined will suffer a net injury, and there will be injury to the outside world and to the world at large".

6) Many authors have found that parts of Viner's analysis were not complete and have thus attempted to enhance the Vinerian theory. They introduced the elasticities of demand or the dynamic effects into the model, and took into account the enlargement of trading bloc over time based on a partial equilibrium (Johnson 1960) or a general equilibrium framework (Meade 1955, Lipsey 1970, Kemp and Wan 1976). 
of different RTAs by upgrading the specialist approach with a larger sample of countries, more contemporaneously dissected RTAs, a longer study period and enhancements in the econometric method.

Finally, our motivation also comes from a desire for proper estimation techniques that can handle the presence of zero trade, which arises prominently in the trade data. Particularly in this case, when the proportion of zero trade reaches approximately $50 \%$ of total potential observations, the choice of a proper estimation technique that can deal with the problem of zero trade is quite important. According to Helpman, Melitz, and Rubinstein (2008), studies could generate biased results by excluding the meaningful insight about pairs of countries that do not trade with each other.

To overcome the zero trade problem, we will estimate the gravity equation by applying the Poisson pseudo maximum likelihood (PPML) estimator that was proposed by Santos Silva and Tenreyro (2006). Moreover, these authors also find that this approach is consistent in the presence of heteroskedasticity in trade data. In this paper, we will show that the PPML estimator can provide convincing results regarding the effects of RTAs on international trade.

This study will contribute to the literature on the ex-post effects of RTAs concerning trade creation and trade diversion by means of an upgraded version of the specialist studies. We decompose the heterogeneous effects of RTAs using a larger sample of countries and plurilateral RTAs. Furthermore, we employ a longer time span and a more appropriate estimation technique than most of the specialist studies focusing on this question. Thus, we are interested in bridging the gap between the specialist and generalist studies in the empirical literature, as advocated by Kohl (2014).

Within the scope of our study, we cover most of the plurilateral "regional" RTAs in force in the world that have been reported to the WTO, which includes a total of eighteen RTAs. We are able to capture the impacts of RTAs around the world and to observe the distinct trade patterns of RTAs that are located in different geographic regions and that have been formed by countries with various levels of development. The main results from the PPML estimator and a theoretically inspired gravity model suggest that in the wake of their entry into force, most RTAs have generated a significant increase in trade flows between member countries. In addition, the impacts of trade agreements on extra-bloc trade are heterogeneous; however, in many cases, they are a detriment to the rest of the world, because they cause a decline in bloc imports from non-members as well as in exports from the rest of the world, implying a trade diversion effect.

The remainder of the paper is organized as follows. Section II summarizes the empirical literature on RTA effects. Section III briefly specifies our econometric approach, the gravity model and describes the dataset. Section IV presents our main empirical results in terms of the average effects of RTAs over the period of 1960 to 2014. Some robustness analysis is 
provided in Section V and Section VI concludes and indicates some caveats in the paper.

\section{Literature Review}

Beginning with only one dummy variable to capture the effects of RTAs on intra-bloc trade, studies on the impacts of RTAs were extended with the addition of second and third dummy variables to measure RTAs' effects on the trade of member countries with non-members. This improvement has changed the way researchers interpret the empirical results; now it is possible to more carefully assess the trade creation and trade diversion effects following the creation of RTAs, as introduced by Viner (1950). The effects on the trade flows between regional blocs and the rest of the world resulting from the formation of RTAs can be examined more clearly with the support of different regional dummy variables. In this section, we demonstrate the path of development of the RTA empirical analysis based on the improvement of the set of regional dummy variables.

In the interest of evaluating the effects of an RTA on trade flows, many studies first enhanced the basic gravity model by including a regional dummy variable to measure its effects on the trade flows between member countries. This dummy represents the sum of trade creation and trade diversion effects generated by the RTA, as pointed out by Soloaga and Winters (2001). The results obtained in various studies including just one regional dummy variable have been conflicting. Based on the cross-section gravity model, Aitken (1973), Brada and Méndez (1985) showed that the European Economic Community (EEC) had significant positive effects on trade flows between participating countries, while the works of Bergstrand (1985) and Frankel, Stein, and Wei (1995) found insignificant effects in the same RTA. Meanwhile, Frankel (1997) found a change in the effects relating to the enlargement of the EEC during the period of 1970 1992 from significantly negative to positive impacts.

In the case of trading blocs in America, Frankel (1997) found that the North American Free Trade Agreement (NAFTA) and the Southern Common Market (Mercosur) had positive and significant impacts on intra-bloc trade by means of pooled estimation over the period of 1970 through 1992, while the bloc effect of the Andean Community is insignificant. Cheng and Wall (2005) and Bussière, Fidrmuc, and Schnatz (2005) found that these RTAs all create a positive impact on intra-bloc trade based on the panel data method with fixed effects. For the European Free Trade Association (EFTA), Frankel, Stein, and Wei (1995) showed that the coefficients for the bloc effect of EFTA were never significant during the study period. In contrast, Aitken (1973) found strong evidence that the intra-bloc trade between EFTA members is above the expected levels predicted from the gravity model following the formation of the bloc, although both studies applied cross-sectional data. 
Since the studies including only a single regional dummy variable were not capable of capturing the effect of an RTA on trade flows between bloc members and non-members, in the late 1990s, many empirical studies added a second regional dummy variable to measure it. This dummy is a binary variable that assumes the value of 1 if one of the two countries in a bilateral country pair participates in a given RTA and the other does not, and 0 otherwise. Frankel (1997) indicates that this variable accounts for the level of openness of an RTA. Studies can identify the trade creation and trade diversion effects of an RTA separately thanks to the combination of the former regional dummy variable and the more recently developed dummy variable. In the cases when the formation of an RTA leads to an increase in intra-bloc trade and promotes extra-bloc trade or keeps the latter unchanged, this RTA is likely to have a trade creation effect. However, if an RTA increases the trade flows between member countries to the detriment of their trade flows with the outsiders, it appears to induce a trade diversion effect, since intra-bloc trade can substitute for the trade flows that come from non-members.

When the openness term of RTAs is taken into account, Frankel (1997) found significantly negative coefficient estimates for trade between members and non-members in the cases of EFTA and NAFTA, along with significant and positive coefficient estimates for intra-bloc trade. The author also found that Mercosur and the free trade area indicated by the Association of South East Asian Nations (ASEAN) have increased the propensity to trade with non-members because the estimated coefficients of both regional dummy variables are positive. For the EEC, Frankel (1997) showed that in 1980 and 1985, the EEC members were more open to trade with the rest of the world than one would predict from the standard gravity variables indicated by the openness coefficient, which was highly significant and positive. By contrast, Bayoumi and Eichengreen (1997) found evidence of negative effects on extra-bloc trade following the formation of the EEC in the 1960s. Lee and Park (2005) showed that the European Union (EU), NAFTA, and Mercosur led to an increase in extra-bloc trade and greater progress in trade between member countries, whereas the Central American Common Market (CACM) and the Common Market for Eastern and Southern Africa (COMESA) contribute to a significant decrease in extra-bloc trade.

Nonetheless, the studies including these two dummy variables seldom precisely identify the trade creation and trade diversion effects of RTAs. Since the dummy variable for the level of openness (extra-bloc trade) covers both of the members' total exports and imports of goods, it is not capable of separating the impact of the trading bloc on the extra-bloc trade regarding exports from the impact regarding imports. As Soloaga and Winters (2001) noted, the import and export flows of member countries may follow different paths. When an RTA improves the trade with non-member countries, the gravity model with two regional dummy variables cannot identify whether this effect comes from the exports toward the rest of the world or the imports from non-members. Similarly, this problem also arises when an RTA has negative 
effects on extra-bloc trade.

The most recent studies, i.e., those published since the $2000 \mathrm{~s}$, once again extend the model by including a third regional dummy variable to create a set of three dummy variables individualized for each RTA. Among these three variables, one measures the intra-bloc trade between participating countries, the second attempts to explain the export flows of member countries toward non-members, and the third variable captures the import flows from the rest of the world to the member countries. The last two dummies seek to indicate the level of overall openness for the trading bloc in terms of export and import flows.

For the purpose of interpreting the effects of a given RTA, when an RTA induces an increase in intra-bloc trade (a positive coefficient) combined with an increase in extra-bloc trade in terms of exports or imports with non-members (a positive coefficient on extra-bloc exports or imports), it identifies that trade is created in terms of export flows or import flows, respectively. By contrast, if an increase in intra-bloc trade combines with a decline in extra-bloc trade concerning exports or imports (a negative coefficient on extra-bloc exports or imports), this situation is determined by an export diversion effect or import diversion effect, respectively.

Regarding the effects of RTAs on welfare, one can identify an RTA as being harmful to non-members when the coefficient on the extra-bloc trade concerning exports to non-members is negative; this leads to a falling inclination of member countries to ship their goods to the rest of the world and results in welfare losses for the outsiders. On the other hand, if it is more costly for the producers within an RTA to produce goods than those in the rest of the world, it indicates inefficiency in the allocation of resources worldwide, which is also detrimental to the outsiders of RTAs (Trotignon 2010).

In a cross-sectional study by Soloaga and Winters (2001), an import creation effect was present in the cases of the EU, EFTA, NAFTA, and ASEAN and negative effects were found on extra-bloc trade for Andean, CACM and Mercosur agreements, on average, over the period of 1980 1996. Carrère (2006) and Trotignon (2010), who employed the panel data approach, also found an increase in the propensity of the EU to export to the rest of the world. Meanwhile, Endoh (1999) pointed to trade creation effect in the EEC over the period of 1960 1994 through all three channels, i.e., intra-bloc trade and extra-bloc trade in terms of both exports and imports. For the Andean Community, Mercosur, NAFTA and ASEAN, Carrère (2006) showed a falling propensity to import from the rest of the world in the wake of the formation of these RTAs, while Trotignon (2010) found opposite effects, as the author demonstrated an increase in extra-bloc trade in terms of imports coming from non-members. Although the two authors both use the panel gravity model, their studies have very conflicting results due to the differences in the econometric methods included in their models.

In summary, many studies have distinctly contributed to the evolution in the empirical analysis of RTA effects on international trade by developing a set of regional dummy variables, 
i.e., going from a single dummy to three dummies. According to our objective, this paper is reasonably in line with the specific studies that use a set of three regional dummy variables individualized for each RTA, which has been the most recent development in the set of RTA dummy variables. Most of the empirical studies that include three regional dummy variables agree on the trade creation effects in terms of the intra-bloc trade following the creation of RTAs. Nonetheless, they are divided concerning the RTA impacts on extra-bloc trade. Soloaga and Winters (2001) and Carrère (2006) show the trade diversion effects in terms of bloc exports and imports for most RTAs, whereas Trotignon (2010) finds trade creation effects regarding the extra-bloc trade for a majority of RTAs. Once again, these mixed results stem mostly from differences between these studies in terms of the study period, the sample of countries, and the choices of explanatory variables and estimation techniques.

\section{Methodology and Data}

\section{A. Econometric approach}

Studies on the ex-post effects of RTAs some have encountered some problems in the gravity model. The first problem, which is the most relevant for this analysis, concerns zero trade flows between country pairs. In some cases, some of the zero trade flows reflect a random rounding error or random missing data. They may also come from the systematic rounding of very low reported values of bilateral trade. In contrast, the zero trade flows found in the database may naturally originate from the fact that bilateral trade does not exist over a period due to the remoteness of those countries, the prohibitive transport costs or the small sizes of the economies, as argued by Frankel (1997), Santos Silva and Tenreyro (2006), and Helpman, Melitz, and Rubinstein (2008). Martin and Pham (2015) also found that most of the bilateral trade flows in aggregate trade data display a real absence of trade. The problem of zero trade flows is quite serious since almost $50 \%$ of the total observations on bilateral trade are zero in the dataset used by Santos Silva and Tenreyro (2006), Helpman, Melitz, and Rubinstein (2008), and Burger, van Oort, and Linders (2009). As a result, the problem of zero trade flows must be seriously considered using proper econometric techniques.

The conventional method for estimating the gravity model is to keep the model in log-linear form. However, this approach is inappropriate, because the log-linearized model is not feasible for observations involving zero trade flow because the natural logarithm of zero is undefined. Hence, several methods have been proposed in the empirical literature to address the zero trade flow problem. One of the most prevalent methods to simply exclude the instances of zero trade from the dataset and then estimate the gravity model on a truncated database of country 
pairs that consists of only positive bilateral trade flows. By omitting observations with zero trade, however, this method overlooks interesting and useful insight into the real nature of zero trade between countries and induces serious problems and biased results, since these zero trade flows are generally not randomly determined, as shown by Burger, van Oort, and Linders (2009) and Martin and Pham (2015).

Other studies choose to not exclude zero trade flows, but use some transformation involving the dependent variable, for instance, adding a small number to the zero trade observation (a value of 1 in most cases) before taking logarithms. Another method uses a Tobit model and keeps the observations involving zero trade. Santos Silva and Tenreyro (2006) argued that these methods induce inconsistent estimates in the case when the constant-elasticity model is used. They also pointed out that the standard methods used to estimate the gravity models can lead to misleading estimated coefficients in the presence of heteroskedasticity, which appears inherently in trade data. If the problem of heteroskedasticity rises in the multiplicative model, then its transformation into log-linear form can lead to a more severe bias in the estimated elasticities. Hence, the authors do not recommend estimating the gravity model based on a log-linearized version.

According to Santos Silva and Tenreyro (2006), the PPML estimator is a natural method to solve the problem of zero trade flows. Specifically, they found that the performance of the PPML estimator is not affected when the proportion of the dependent variable with zero trade is substantial. Since the gravity model is directly estimated from its multiplicative form, where the dependent variable is measured in levels instead of linearizing the model by using logarithms, the zero trade flow problem is handled well. Moreover, they found that the PPML method appears to yield more robust and consistent results than the other econometric techniques in the presence of heteroskedasticity. Several recent empirical analyses on the gravity model, such as those by Westerlund and Wilhelmsson (2011), Anderson and Yotov (2012), Anderson and Yotov (2016), and Anderson, Larch, and Yotov (2018), have included the PPML method and praised the estimator as a new central tool to assess international trade.

The second problem in the gravity model encountered by many analyses on trade policies involves the endogeneity of RTAs when there is potential reverse causality between RTAs and a higher level of bilateral trade between country pairs. According to the hypothesis of "natural trading partners" or "natural trading blocs" that was introduced by Krugman (1991), countries show a propensity to form RTAs with other partner countries for which there are potentially higher trade volumes between them. Furthermore, there are still many unobserved factors between country pairs that may increase bilateral trade and promote the establishment of an RTA concurrently. As a result, the estimated coefficients are likely to be biased since the RTA dummy variable featuring the existence of the trade agreement is potentially correlated with the error term in the gravity equation. 
A majority of empirical studies using cross-sectional data and including dummy variables for trade agreements do not take the issue of RTA endogeneity into account. In the extant literature, Trefler (1993) and Lee and Swagel (1997) published the first studies that attempted to adjust for the endogeneity of trade policies on a cross-sectional framework by using instrumental variables7). By contrast, Magee (2003) recently found that the instrumental-variables approach does not appear to be efficient in adjusting the issue of endogeneity bias of a binary RTA dummy variable. The author pointed out that it is difficult to find instruments that are unlikely to be correlated with the error term of the gravity equation.

An alternative method of addressing potential endogeneity with RTAs is to estimate the gravity model with the fixed effects (within) estimator that includes bilateral fixed effects for country pairs. According to Baier and Bergstrand (2007), these fixed effects can address the issue of RTA endogeneity bias because they are able to better deal with the unobserved heterogeneity among pairs of countries - one of the most important sources of the endogeneity problem related to RTAs. In addition, Head and Mayer (2013) found that due to the lack of adequate instrumental variables, the fixed effects (within) estimator is able to control for part of the potential RTA endogeneity bias. Filippini and Molini (2003) likewise used the country-pair fixed effects model and found that long-term data do not have the endogeneity problem and produce unbiased results.

The third prominent challenge to address in the gravity model is Anderson and van Wincoop (2003)'s multilateral resistance terms. According to the authors, studies are more likely to be biased because they fail to take into account unobserved price indices. Therefore, their multilateral resistance terms incorporate three trade resistance factors in international trade, which are the bilateral trade barriers, the exporter country's trade resistance toward all other destinations, and the importer country's trade resistance toward all other trading partners.

To carry out an easier computational method for taking into account these multilateral resistance term variables in a panel data setting, Anderson and van Wincoop (2003) and Feenstra (2004) suggest the use of time-variant fixed effects for both the exporter and importer countries. This type of fixed effect can produce unbiased results concerning the gravity estimates and has become the preferred econometric technique of many researchers, like Baier and Bergstrand (2007), Magee (2008), and Kohl (2014).

Our study aims to address these significant problems in the gravity model with the help of the PPML estimator and a theoretically inspired gravity model with a proper specification of fixed effects.

7) Trefler (1993) and Lee and Swagel (1997) concluded that the impacts of trade liberalization policies tend to be underestimated without considering instrumental variables. 


\section{B. Gravity methodology}

To estimate the effects of RTAs on members' trade, we employ the basic gravity equation that has usually been used in international trade analysis. We first augment the model with the dummy variables for eighteen plurilateral RTAs. This brings forth the following equation:

$$
X_{i j t}=\beta_{0}\left(G D P_{i t}\right)^{\beta_{1}}\left(G D P_{j t}\right)^{\beta_{2}}\left(D I S T_{i j}\right)^{\beta_{3}} e^{\beta_{4}\left(L A N G_{i j}\right)} e^{\beta_{5}\left(\operatorname{CONTIG~}_{i j}\right)} e^{\alpha_{l \text { thra }}^{k}\left(R T A^{k}{ }_{-}{ }_{-1 t r a}{ }_{i j t}\right)} \psi_{i j t}
$$

where $X_{i j t}$ is the value of trade flow in terms of goods in current dollar values from exporter country $i$ to importer country $j$ at time $t . G D P_{i t}$ and $G D P_{j t}$ are the proxies for the exporter and importer country's economic size (gross domestic product), respectively. The impact of these two variables on bilateral trade flows is expected to be positive. $D I S T_{i j}$ is the distance measured in kilometers between country $i$ and country $j$ and we expect its impact on trade flows to be negative. $L A N G_{i j}$ is a binary variable that takes the value of 1 if $i$ and $j$ share a common language, and 0 otherwise. The effect of this dummy variable is expected to be positive, given that a common language between two trading partners could facilitate trade deals and, thus, reduce trade costs. CONTIG $G_{i j}$ is a binary variable that takes the value of 1 if $i$ and $j$ have a common land border, and 0 otherwise. The effect of sharing a common land border between two countries is likely to have a positive effect on bilateral trade flows. $R T A^{k}$ Intra $_{i j t}$ assumes the value of 1 if both trading partners $i$ and $j$ have participated in a common $R T A^{k}$ at time $t$, and 0 otherwise. This dummy variable dissects the intra-bloc trade. Finally, $e$ is the natural logarithm base, and $\psi_{i j t}$ denotes the error term.

The traditional approach to estimating Equation (1) in the literature is to transform it to a linear model by taking the logarithms, which leads to the following equation:

$$
\begin{aligned}
\ln \left(X_{i j t}\right)= & \beta_{0}+\beta_{1} \ln \left(G D P_{i t}\right)+\beta_{2} \ln \left(G D P_{j t}\right)+\beta_{3} \ln \left(D I S T_{i j}\right)+\beta_{4}\left(L A N G_{i j}\right)+\beta_{5}\left(C O N T I G_{i j}\right) \\
& +\alpha_{\text {Intra }}^{k}\left(R T A^{k} \text { Intra }_{i j t}\right)+\varepsilon_{i j t}
\end{aligned}
$$

where $\varepsilon_{i j t}\left(=\ln \psi_{i j t}\right)$ is the error term of Equation (2). However, the log-linear model struggles with observations involving zero trade value $\left(X_{i j t}=0\right)$ because the natural logarithm of zero is undefined.

As explained in the previous section, this study applies the PPML estimator to deal with 
the challenges that the log-linear gravity equation has failed to overcome. Moreover, we employ a fixed effects version of the gravity equation that includes the country-pair and time-varying exporter and importer fixed effects to control for the endogeneity of RTAs and unobservable multilateral resistance terms, respectively.

Thus, the PPML estimation is used to estimate the gravity model, which is written as follows:

$$
\begin{aligned}
X_{i j t} & =\exp \left[\beta_{0}+\beta_{1} \ln \left(G D P_{i t}\right)+\beta_{2} \ln \left(G D P_{j t}\right)+\beta_{3} \ln \left(D I S T_{i j}\right)+\beta_{4}\left(L A N G_{i j}\right)+\beta_{5}\left(\text { CONTIG }_{i j}\right)\right. \\
& \left.+\alpha_{\text {Intra }}^{k}\left(R T A^{k} \text { Intra }_{i j t}\right)+\gamma_{i t}+\eta_{j t}+\lambda_{i j}\right]+\varepsilon_{i j t}
\end{aligned}
$$

where $\gamma_{i t}$ and $\eta_{j t}$ denote the time-varying exporter and importer fixed effects, respectively, and $\lambda_{i j}$ represents the bilateral fixed effects.

Equation (3) remarkably enhances the gravity estimates. However, Equation (3) cannot take into account the RTA variables on extra-bloc trade. Thus, this indicates an important limitation of the gravity specification with exporter-year and importer-year fixed effects. Note that the importer-year fixed effect controls for the variation in the importer country's overall imports in year $t$. Including this fixed effect does not allow us to simultaneously distinguish the evolution in RTA intra-bloc imports and the change in the RTA extra-bloc imports, because, as argued by Magee (2008), the latter two values constitute the total change in the importer's total imports. The exporter-year fixed effect behaves in a similar way.

Accordingly, to analyze the impacts of a trade agreement on its intra-bloc trade as well as its extra-bloc trade in terms of bloc exports and imports, we estimate the following gravity specification that omits exporter-year and importer-year fixed effects:

$$
\begin{aligned}
X_{i j t} & =\exp \left[\beta_{0}+\beta_{1} \ln \left(G D P_{i t}\right)+\beta_{2} \ln \left(G D P_{j t}\right)+\beta_{3} \ln \left(D I S T_{i j}\right)+\beta_{4}\left(L_{A N G_{i j}}\right)+\beta_{5}\left(\text { CONTIG }_{i j}\right)\right. \\
& \left.+\alpha_{\text {Intra }}^{k}\left(R T A^{k} \text { Intra }_{i j t}\right)+\alpha_{X}^{k}\left(R T A^{k}{ }_{-} X_{i j t}\right)+\alpha_{M}^{k}\left(R T A^{k}{ }_{-} M_{i j t}\right)+\lambda_{i j}+\vartheta_{t}\right]+\varepsilon_{i j t}
\end{aligned}
$$

where $\vartheta_{t}$ denotes year effects to capture common yearly trends and shocks.

Regarding the additional RTA variables, $R T A^{k}{ }_{-} X_{i j t}$ assumes the value of 1 if exporter country $i$ belongs to an RTA in which importer country $j$ does not participate at time $t$, and 0 otherwise. This dummy variable captures the impact of the bloc exports to the rest of the world. Variable $R T A^{k}{ }_{i j t}$ assumes the value of 1 if importer country $j$ belongs to an RTA in which exporter country $i$ does not participate at time $t$, and 0 otherwise. This dummy variable tests the impact of the bloc imports coming from the rest of the world. 
Hence, the set of prime variables of interest (three RTA dummy variables) allows us to assess the influence of the precisely identified RTA trade effects (introduced by Viner 1950) on member countries and multilateral trading system. To capture the trade creation and trade diversion effects of a specific RTA, we need to examine the signs of the coefficients of these RTA variables, which are $\alpha_{\text {Intra }}^{k}, \alpha_{X}^{k}, \alpha_{M}^{k}$, respectively. If $\alpha_{\text {Intra }}^{k}>0$, meaning the formation of an RTA stimulates intra-bloc trade creation effects between member countries, when both member countries join the RTA, additional trade is induced. More precisely, the domestic production of member countries or the bloc imports coming from the rest of the world can be substituted with the increase in intra-bloc trade resulting from the formation of the RTA. Thus, the coefficients of $\alpha_{X}^{k}$ and $\alpha_{M}^{k}$ will determine the trade creation and trade diversion effects for a specific RTA. We demonstrate our method of analyzing the signs of the RTA coefficients, inspired by Soloaga and Winters (2001), Carrère (2006) and Trotignon (2010), in Table 1 as follows.

Table 1. Trade creation and trade diversion effects of RTA coefficients

\begin{tabular}{cccc}
\hline \multicolumn{3}{c}{ Sign of RTA coefficients } & \\
\cline { 1 - 3 }$\alpha_{\text {Intra }}^{k}$ & $\alpha_{X}^{k}$ & $\alpha_{M}^{k}$ & Trade creation and Trade diversion effects \\
\hline 0 & $>0$ & $>0$ & Intra-bloc trade creation/Export creation/Import creation \\
$>0$ & $>0$ & $<0$ & Intra-bloc trade creation/Export creation/Import diversion \\
$>0$ & $<0$ & $>0$ & Intra-bloc trade creation/Export diversion/Import creation \\
$>0$ & $<0$ & $<0$ & Intra-bloc trade creation/Export diversion/Import diversion \\
\hline
\end{tabular}

(Source) Author.

In summary, when $\alpha_{\text {Intra }}^{k}>0$ combines with $\alpha_{X}^{k}>0\left(\alpha_{M}^{k}>0\right)$, it indicates trade creation in terms of bloc exports to the rest of the world and bloc imports from the rest of the world. The variable $\alpha_{\text {Intra }}^{k}>0$ coupled with $\alpha_{X}^{k}<0$ or $\alpha_{M}^{k}<0$ displays trade diversion regarding bloc exports or bloc imports. The term "export creation/diversion" is used to illustrate higher/lower trade when the exporter country is a member of the RTA and the importer country is not, whereas "import creation/diversion" is used for increased or reduced trade when the importer country belongs to the RTA but the exporter country does not. If $\alpha_{X}^{k}$ and $\alpha_{M}^{k}$ are both negative, then we compare the value of $\alpha_{\text {Intra }}^{k}$ with the absolute value of the sum of $\alpha_{X}^{k}$ and $\alpha_{M}^{k}$ to examine whether the trade diversion regarding bloc exports and bloc imports can completely outweigh the intra-bloc trade creation (in the case when $\alpha_{\text {Intra }}^{k}<\left|\alpha_{X}^{k}+\alpha_{M}^{k}\right|$ ). Additionally, studying the signs of the RTA coefficients also helps us to assess the welfare of non-members. For instance, when $\alpha_{\text {Intra }}^{k}>0$ combines with $\alpha_{X}^{k}<0$, we find a decrease in the welfare of non-members through 
the export diversion effect.

\section{Data}

The model is estimated based on a dataset that includes 160 countries over the period of 1960 through 2014. Appendix 1 enumerates the countries used in the study. These countries, on average, accounted for over $95 \%$ of the total trade in the world over the period of 55 years. The nominal bilateral trade data are collected Direction of Trade Statistics (DOTS) from the International Monetary Fund (IMF). The nominal GDPs are from Head, Mayer, and Ries (2010) and the World Bank's World Development Indicators. Here we follow the proposition in Baldwin and Taglioni (2006) to remedy their "bronze-medal mistake" in the gravity model estimations. They employed undeflated trade values with a structure of bilateral and time-varying country fixed effects to remove any issues emerging from the omission of the deflation of trade. Consequently, the estimates using real trade flows or nominal trade flows are interchangeable.

The set of control variables involving geographical and cultural characteristics, such as bilateral distance, contiguity, and common language, are sourced from the CEPII gravity database. The dummy variables for RTAs are created from the WTO Regional Trade Agreements Information System (RTA-IS) ${ }^{8}$ ) complemented with the database of Baier and Bergstrand (2007). In this analysis, we include only full (no partial) plurilateral RTAs covering the liberalization of trade in goods that are notified to the GATT/WTO under GATT Article XXIV or the Enabling Clause for developing countries, which are free trade agreements and customs unions. The date when a given RTA enters into force is used to define whether the dummies for this RTA will take the value of 1 or 0 .

To capture the impacts of the wave of regionalism on the multilateral trading system around the world, we consider eighteen RTAs that exist in different regions. Many RTAs were either created or revamped during the late 1980s and early 1990s, such as the ASEAN Free Trade Agreement, NAFTA, Mercosur, Andean Community, and CACM. During the 1990s and 2000s, we also witnessed the great extension of the EU along with the reduction in membership in the EFTA and the establishment of other RTAs located mainly in Africa, Asia, and Central America. Appendices 2 and 3 list of all of the RTAs, their geographic areas and member countries that are included in the study.

Figure 1 presents the share of an individual RTA's exports and imports in world trade following its entry into force. Most RTAs have had a trivial role in world trade, with the exception of the EU and NAFTA. However, the EU and NAFTA's share in world exports and imports experienced a significant downward trend (from approximately 46\% in 1960 to about $30 \%$ in 2014 and from $20 \%$ in 1996 to $17 \%$ in 2014, in the case of the EU and NAFTA,

8) https://rtais.wto.org/UI/PublicMaintainRTAHome.aspx 
Figure 1. Share of individual RTA's trade flows in global trade following its entry into force, 1960 2014

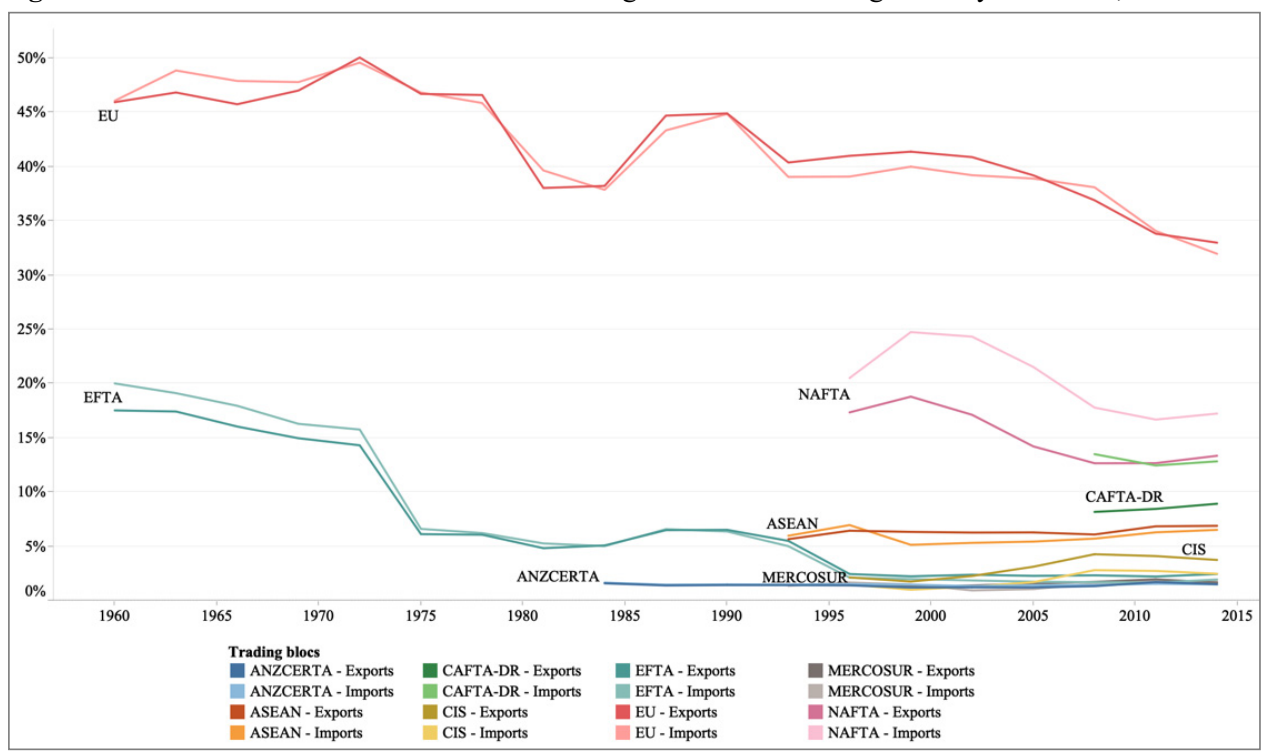

(Note) This figure only shows the trading blocs with a share of their exports and imports more than $1 \%$ in world trade.

(Source) Author's calculations based on the IMF's DOTS.

respectively). This suggests that the trade flows of these two RTAs encountered smaller increases in value than the rest of the world.

Figure 2 reports the share of intra-bloc trade in each RTA's total trade value since its entry into force. Only the EU and NAFTA have a share of intra-bloc trade more than $50 \%$ of their total trade, on average, after their formation, followed by ASEAN and the Commonwealth of Independent States (CIS), with more than 20\%. Interestingly, the CIS experienced a steady decrease in its share of intra-bloc trade. The intra-bloc trade of other plurilateral RTAs is proving to be very negligible compared with their total trade flows.

Because this paper takes into account unidirectional trade flows as suggested by Baldwin and Taglioni (2006) rather than the average of the two-way exports, our dataset presents a panel structure consisting of a total of 1,399,200 potential annual observations for 25,440 pairs of countries. After missing values are removed, the sample covers 1,136,548 observations.

Compared to other empirical studies involving the assessment of RTA effects on international trade, this work has a fairly large sample. Based on the same trade database (IMF's DOTS), Frankel (1997) pooled data from 1970 through 1992 with five-year intervals and examined a total of 6,102 observations; Baier and Bergstrand (2007)'s work included a sample of 47,081 observations covering 96 countries from 1960 to 2000 at five-year intervals. Carrère (2006) assesses the impacts of RTAs with a sample comprising 240,691 observations over the period of 1962 1996. Appendix 4 describes the descriptive statistics of the variables. 
Figure 2. Share of intra-bloc trade in each trading bloc's total trade value since its entry into force, 1960 2014

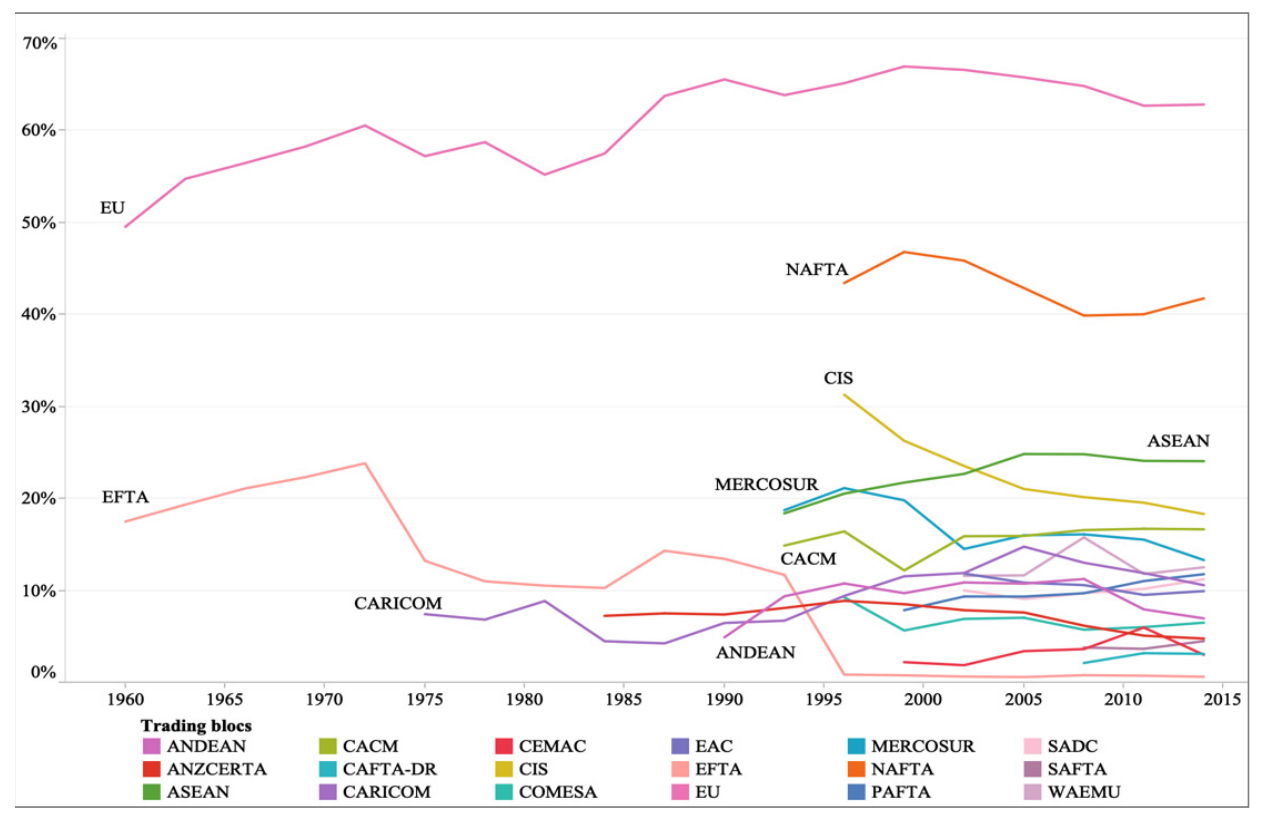

(Source) Author's calculations based on the IMF's DOTS.

Of all of the observations, $32,500(2.3 \%)$ belong to an RTA that is included in our study; these are observations of 1,682 country pairs (6.6\%). Among these eighteen RTAs, the EU has the most member countries; it has 27 countries9) and covers 11,910 observations over a time span of 55 years. In comparison, the Australia-New Zealand Closer Economic Relations Trade Agreement (ANZCERTA) involves only two country pairs and covers the least number observations (64 observations).

Regarding the issue of zero trade flows, approximately $50.5 \%$ of the observations are zero ${ }^{10}$. This proportion of zero trade is similar to other empirical studies. For instance, $47.6 \%$ of the observations in Santos Silva and Tenreyro (2006), and about half of the observations in Helpman, Melitz, and Rubinstein (2008) and Burger, van Oort, and Linders (2009) involve zero trade flows. Table 2 features the patterns of zero trade flows in the dataset based on a bilateral distance set and sets of exporter and importer GDPs. We find that the percentage of zero trade flows are higher in the set of the $1^{\text {st }}$ to the $33^{\text {th }}$ percentile of exporter GDP and importer GDP $(72.8 \%$ and $67 \%$, respectively) than in the set of the $67^{\text {th }}$ to the $99^{\text {th }}$ percentile, which corresponds to countries having greater GDP. Therefore, it seems that smaller countries tend to export to a much smaller number of partner countries than others. In addition, countries are more likely to export

9) We do not include Croatia in our sample since Croatia recently joined the EU in mid-2013.

10) Note that if missing values in trade flows between exporter and importer countries for over ten consecutive years are recorded, we consider them as zero trade flows, following Brun et al. (2005), and Felbermayr and Kohler (2006). 
Table 2. Percentage of zero trade flows

\begin{tabular}{lccc}
\hline & Bilateral distance & Exporter GDP & Importer GDP \\
\hline $1^{\text {st }}$ to $33^{\text {th }}$ percentile & $43.0 \%$ & $72.8 \%$ & $67.0 \%$ \\
$34^{\text {th }}$ to $66^{\text {th }}$ percentile & $51.3 \%$ & $47.3 \%$ & $49.1 \%$ \\
$67^{\text {th }}$ to $99^{\text {th }}$ percentile & $57.3 \%$ & $36.7 \%$ & $39.7 \%$ \\
\hline
\end{tabular}

(Source) Author's calculations.

to partner countries that are within closer proximity, shown by the percentage of zero trade flows increasing with bilateral distance. The findings from our dataset are in line with the literature, i.e., that bilateral trade is likely absent among small and remote countries due to prohibitive trade costs.

Figure 3 a shows a histogram and a kernel density plot for the proportion of zeros in the exports of 160 countries included in the study. Among them, 18 countries have total zero trade flows for under $15 \%$ of their potential export flows with trading partners from 1960 through 2014. All of these countries are developed countries. Nonetheless, the majority of countries have zero export trade flows with approximately $40 \%$ to $70 \%$ of their potential partner countries.

Figure 3. Proportion of zero trade over the period of 1960 2014

(a) On country-level export flows

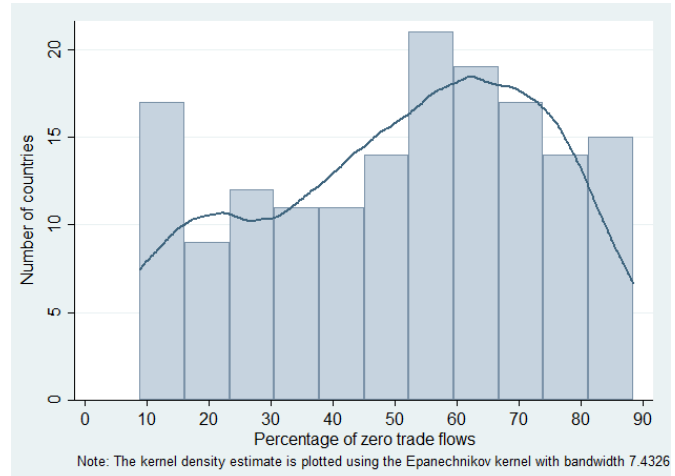

(b) On country-pair-level export flows

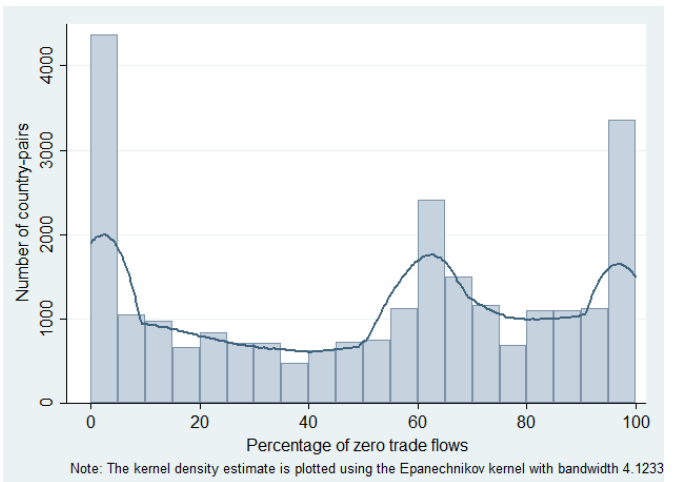

(Source) Author's calculations.

On the country-pair level, Figure $3 \mathrm{~b}$ presents a histogram and a kernel density plot for the proportion of zero exports involving 25,440 country pairs. There are 3,975 country pairs that have no zero trade flows over the 55 year period and approximately $49 \%$ of the total country pairs have zero trade flows for $60 \%$ to $100 \%$ of the time. In particular, we find that 2,399 country pairs, most of which include small countries or remote countries, have zero trade entirely during the study period.

Additionally, Figure 3 shows that the zero trade flows are nonrandomly distributed, as can be expected from trade theory (Burger, van Oort, and Linders 2009). In summary, the dataset 
used in this paper suggest again that the issue of zero trade flows is quite crucial, with $50.5 \%$ of the observations having zero trade flows. Thus, this finding justifies the need to gather the valuable information that is contained in the zero trade data to address the lack of trade in certain country pairs.

\section{Empirical Results}

\section{A. Baseline model dissecting the impacts of RTAs on intra-bloc trade}

Table 3 (Panel A) presents estimates of the impacts of the regionalism caused by different RTAs on trade flows. We first carry out some preliminary tests to determine the presence of heteroskedasticity and serial correlation. The White and Wooldridge tests indicate problems of heteroskedasticity and serial correlation in our dataset; therefore, the standard errors from the estimations are clustered by country pair.

The results in Panel A, Table 3 are for the traditional gravity model that only includes the variables for different RTAs' intra-bloc trade, the logs of GDPs, distance, and some other bilateral control dummies as explanatory variables, as described in Equation (2). Then, we investigate the impact of controlling for a more structural set of fixed effects. Columns (1) to (3) provide the coefficients estimated using the PPML method. For comparison, Columns (4) and (5) list the estimation outcomes resulting from the fixed effects (FE) (within) estimator, which will be discussed later.

At first glance, Column (1) presents the PPML results of the basic gravity model, in which the GDP level of the exporter and importer countries are highly statistically significant at the $1 \%$ level and have the expected positive sign, because bilateral trade flows increase with the size of the GDP of the trading partners. The coefficient on distance is negative and statistically significant at the $1 \%$ level as well. The estimated coefficients on contiguity and common language are also positive and highly significant, as expected.

Since the primary interest in this study is to assess the impact of various RTAs on members' trade, we mainly focus on the RTA dummy variables. The traditional gravity model without any FE in Column (1) shows significant intra-bloc trade in most regional blocs. The median RTA in the first column is estimated to raise intra-bloc trade by $127.7 \%\left(=100 *\left(e^{0.823}-1\right)\right)$. Since this specification ignores the recent developments in the theoretical foundations of the gravity model, these results may suffer from bias.

Column (2) puts the FE for each country pair and for every year into the dissection, which is similar to Equation (4). We find that when bilateral and year FE are controlled for, the impact of the median RTA on the members' intra-bloc trade decreases to $74.9 \%$, which is approximately 
Table 3. Estimated impacts of RTAs on intra-bloc trade

\begin{tabular}{|c|c|c|c|c|c|c|c|}
\hline \multirow{2}{*}{ Specifications } & \multicolumn{5}{|c|}{ Panel A } & \multicolumn{2}{|c|}{ Panel B } \\
\hline & \multicolumn{3}{|c|}{ PPML } & \multicolumn{2}{|c|}{ FE (within) } & \multirow{2}{*}{$\begin{array}{c}\text { PPML } \\
X_{i j t} \\
\end{array}$} & FE (within) \\
\hline \multirow{2}{*}{ Variables } & \multicolumn{3}{|c|}{$X_{i j t}$} & \multicolumn{2}{|c|}{$\ln \left(X_{i j t}\right)$} & & $\ln \left(X_{i j t}\right)$ \\
\hline & (1) & (2) & (3) & (4) & (5) & (6) & (7) \\
\hline \multirow[t]{2}{*}{$\ln \left(G D P_{i t}\right)$} & $0.774 * * *$ & $0.679 * * *$ & & $0.712 * * *$ & & & \\
\hline & $(0.014)$ & $(0.038)$ & & $(0.017)$ & & & \\
\hline \multirow[t]{2}{*}{$\ln \left(G D P_{j t}\right)$} & $0.786^{* * *}$ & $0.651 * * *$ & & $0.699 * * *$ & & & \\
\hline & $(0.019)$ & $(0.055)$ & & $(0.014)$ & & & \\
\hline \multirow{2}{*}{$\ln \left(D I S T_{i j}\right)$} & $-0.645 * * *$ & & & & & & \\
\hline & $(0.035)$ & & & & & & \\
\hline \multirow[t]{2}{*}{$C O N T I G_{i j}$} & $0.518^{* * *}$ & & & & & & \\
\hline & $(0.095)$ & & & & & & \\
\hline \multirow[t]{2}{*}{$L A N G_{i j}$} & $0.425 * * *$ & & & & & & \\
\hline & $(0.073)$ & & & & & & \\
\hline \multirow[t]{2}{*}{$A N D E A N \_$Intra } & -0.168 & $0.677 * * *$ & $0.969 * * *$ & $1.529 * * *$ & $1.444 * * *$ & $0.986^{* * *}$ & $1.421 * * *$ \\
\hline & $(0.181)$ & $(0.134)$ & $(0.165)$ & $(0.154)$ & $(0.212)$ & $(0.184)$ & $(0.207)$ \\
\hline \multirow[t]{2}{*}{ ANZCERTA_Intra } & $1.241^{* * *}$ & 0.013 & $0.642 * * *$ & $0.557 * *$ & $0.381 * * *$ & $0.613^{* * *}$ & $0.417 * * *$ \\
\hline & $(0.087)$ & $(0.189)$ & $(0.204)$ & $(0.264)$ & $(0.111)$ & $(0.220)$ & $(0.107)$ \\
\hline \multirow[t]{2}{*}{$A S E A N \_$Intra } & $1.526^{* * *}$ & 0.009 & -0.206 & $0.798 * * *$ & $-0.494 * * *$ & -0.192 & $-0.479 * * *$ \\
\hline & $(0.145)$ & $(0.171)$ & $(0.129)$ & $(0.169)$ & $(0.144)$ & $(0.136)$ & $(0.149)$ \\
\hline \multirow[t]{2}{*}{$C A C M$ Intra } & $0.823 * * *$ & 0.007 & $-0.315^{*}$ & $0.259 * * *$ & 0.176 & $-0.335^{*}$ & $0.308^{*}$ \\
\hline & $(0.201)$ & $(0.139)$ & $(0.179)$ & $(0.098)$ & $(0.133)$ & $(0.196)$ & $(0.158)$ \\
\hline \multirow[t]{2}{*}{ CAFTADR_Intra } & $0.225 * *$ & 0.026 & $0.130 *$ & $0.710 * * *$ & $0.585 * * *$ & 0.107 & $0.553 * * *$ \\
\hline & $(0.114)$ & $(0.110)$ & $(0.079)$ & $(0.121)$ & $(0.134)$ & $(0.082)$ & $(0.145)$ \\
\hline \multirow[t]{2}{*}{ CARICOM_Intra } & $1.995 * * *$ & -0.278 & $0.789 * * *$ & -0.117 & $1.140 * * *$ & $0.762 * *$ & $1.187 * * *$ \\
\hline & $(0.281)$ & $(0.293)$ & $(0.289)$ & $(0.186)$ & $(0.207)$ & $(0.369)$ & $(0.215)$ \\
\hline \multirow[t]{2}{*}{ CEMAC_Intra } & $-0.691 * *$ & -0.404 & 0.055 & $-0.933 * *$ & -0.055 & 0.056 & 0.029 \\
\hline & $(0.333)$ & $(0.258)$ & $(0.333)$ & $(0.399)$ & $(0.364)$ & $(0.341)$ & $(0.360)$ \\
\hline \multirow[t]{2}{*}{ CIS_Intra } & $1.069 * * *$ & $1.731 * * *$ & $-0.565 * * *$ & $-0.341 * * *$ & $-1.049 * * *$ & 0.376 & $-0.851^{* * *}$ \\
\hline & $(0.222)$ & $(0.265)$ & $(0.126)$ & $(0.130)$ & $(0.169)$ & $(0.279)$ & $(0.181)$ \\
\hline \multirow[t]{2}{*}{ COMESA_Intra } & $-0.465 * * *$ & 0.135 & $0.907 * * *$ & $0.317 * * *$ & $0.910 * * *$ & $0.926^{* * *}$ & $0.822 * * *$ \\
\hline & $(0.170)$ & $(0.124)$ & $(0.165)$ & $(0.115)$ & $(0.119)$ & $(0.187)$ & $(0.133)$ \\
\hline \multirow[t]{2}{*}{ EAC_Intra } & $0.927 * * *$ & -0.193 & -0.015 & $0.450 * *$ & $0.895 * * *$ & -0.126 & $0.905 * * *$ \\
\hline & $(0.352)$ & $(0.160)$ & $(0.220)$ & $(0.203)$ & $(0.270)$ & $(0.249)$ & $(0.302)$ \\
\hline EFTA_Intra & 0.239 & $0.365^{* * *}$ & -0.088 & $0.348^{* * *}$ & 0.006 & $-0.110^{*}$ & -0.016 \\
\hline & $(0.194)$ & $(0.077)$ & $(0.060)$ & $(0.053)$ & $(0.089)$ & $(0.063)$ & $(0.092)$ \\
\hline EU_Intra & -0.010 & $0.408 * * *$ & $0.496^{* * *}$ & $0.596 * * *$ & $0.926^{* * *}$ & $0.517 * * *$ & $0.943 * * *$ \\
\hline & $(0.081)$ & $(0.046)$ & $(0.040)$ & $(0.029)$ & $(0.040)$ & $(0.041)$ & $(0.042)$ \\
\hline MERCOSUR_Intra & $0.300 * *$ & $0.579 * * *$ & $0.746^{* * *}$ & $0.855^{* * *}$ & $0.500 * * *$ & $0.772 * * *$ & $0.476^{* *}$ \\
\hline & $(0.135)$ & $(0.146)$ & $(0.151)$ & $(0.089)$ & $(0.179)$ & $(0.160)$ & $(0.185)$ \\
\hline
\end{tabular}


Table 3. Continued

\begin{tabular}{|c|c|c|c|c|c|c|c|}
\hline \multirow{2}{*}{ Specifications } & \multicolumn{5}{|c|}{ Panel A } & \multicolumn{2}{|c|}{ Panel B } \\
\hline & \multicolumn{3}{|c|}{ PPML } & \multicolumn{2}{|c|}{ FE (within) } & PPML & FE (within) \\
\hline \multirow{2}{*}{ Variables } & \multicolumn{3}{|c|}{$X_{i j t}$} & \multicolumn{2}{|c|}{$\ln \left(X_{i j t}\right)$} & $X_{i j t}$ & $\ln \left(X_{i j t}\right)$ \\
\hline & $(1)$ & (2) & (3) & (4) & $(5)$ & (6) & (7) \\
\hline \multirow[t]{2}{*}{ NAFTA_Intra } & $0.485 * * *$ & 0.202 & $0.240 * * *$ & $0.996^{* * *}$ & 0.047 & $0.211 * * *$ & 0.035 \\
\hline & $(0.171)$ & $(0.132)$ & $(0.065)$ & $(0.213)$ & $(0.125)$ & $(0.065)$ & $(0.127)$ \\
\hline \multirow[t]{2}{*}{ PAFTA_Intra } & $-0.476^{* * *}$ & -0.192 & $0.298^{*}$ & $0.407 * * *$ & $0.520 * * *$ & 0.269 & $0.579 * * *$ \\
\hline & $(0.174)$ & $(0.149)$ & $(0.161)$ & $(0.095)$ & $(0.107)$ & $(0.168)$ & $(0.113)$ \\
\hline \multirow[t]{2}{*}{$S A D C_{\text {_Intra }}$} & $1.233 * * *$ & $0.559 * * *$ & $0.720 * * *$ & $0.617^{* * *}$ & $0.790 * * *$ & $0.671^{* * *}$ & $0.857 * * *$ \\
\hline & $(0.238)$ & $(0.129)$ & $(0.161)$ & $(0.182)$ & $(0.211)$ & $(0.164)$ & $(0.237)$ \\
\hline \multirow[t]{2}{*}{ SAFTA_Intra } & $-0.984 * *$ & $0.327 * * *$ & -0.021 & 0.172 & $-0.518 * * *$ & -0.064 & $-0.462 * *$ \\
\hline & $(0.447)$ & $(0.108)$ & $(0.150)$ & $(0.245)$ & $(0.174)$ & $(0.135)$ & $(0.188)$ \\
\hline \multirow[t]{2}{*}{ WAEMU_Intra } & $1.040^{* * *}$ & 0.026 & $0.494 * * *$ & 0.062 & $0.688^{* * *}$ & $0.355^{* *}$ & $0.620 * * *$ \\
\hline & $(0.288)$ & $(0.145)$ & $(0.181)$ & $(0.219)$ & $(0.201)$ & $(0.176)$ & \\
\hline Observations & $1,136,548$ & $1,039,417$ & 994,096 & 652,223 & 652,197 & 331,439 & 223,977 \\
\hline Country pairs & 22,847 & 22,847 & 22,847 & 22,146 & 22,146 & 22,031 & 20,737 \\
\hline $\begin{array}{l}\text { Exporter-year, } \\
\text { Importer-year FEs }\end{array}$ & No & No & Yes & No & Yes & Yes & Yes \\
\hline Country-pair FEs & No & Yes & Yes & Yes & Yes & Yes & Yes \\
\hline Year FEs & No & Yes & No & Yes & No & No & No \\
\hline
\end{tabular}

(Notes) This table reports estimates of the effects of eighteen plurilateral RTAs. Different settings of fixed effects are used across various specifications. Coefficient estimates of the fixed effects are omitted for reasons of brevity. All estimates are obtained in Panel A with data built over consecutive years during the period of 1960 2014. Columns (1), (2), and (3) employ the PPML estimator. Columns (4) and (5) use the panel data technique with the fixed effects (within) estimator. The dependent variable in the PPML regression is the export flows in levels. The dependent variable in the fixed effects (within) regression is the natural $\log$ of the export flows. Panel B employs the data with 3-year intervals. Standard errors are reported in parentheses and clustered by country pair. Respectively, *,**, and $* * *$ denote significance at the level of $10 \%, 5 \%$, and $1 \%$.

half of the value in Column (1). We show evidence that the gravity models without bilateral FE tend to overestimate the impact of RTAs on trade because the countries engaging in RTAs show a preference for country pairs with historically significant levels of bilateral trade.

Column (3) shows the coefficient outcomes resulting from the preferred specification: Equation (3) with time-variant FE for exporters and importers as well as country-pair FE ${ }^{11}$. Not surprisingly, the GDP and bilateral control variables are perfectly collinear with the set of country-year and bilateral FE, respectively, and are thus not determined. The results in terms of the impacts of the RTAs on the intra-bloc trade reinforce the results from Column (2). Including exporter-year and importer-year FE in the model also tends to make the estimated coefficients of the regional

11) By means of the Stata package ppml_panel_sg that was written by Larch et al. (2017), it is computationally possible to estimate these nonlinear regression models with high-dimensional fixed effects (a total of 43,040 potential dummies in terms of exporter-year, importer-year and country-pair fixed effects for the complete dataset). See Larch et al. (2017) for further details. 
bloc smaller. Hence, in Specification (3), the median RTA is shown to increase intra-bloc trade by only $64.2 \%$.

Taking a closer look at the individual RTA effects, 11 of the 18 regional blocs remarkably increase the members' trade within the bloc. Significant negative RTA impacts on intra-bloc trade are observed for CIS and CACM. Conversely, insignificant negative impacts are observed for ASEAN, the South Asian Free Trade Agreement (SAFTA), and the East African Community (EAC). Most of the coefficients on regional agreements are consistent and comparable between Column (2) and Column (3). However, some RTAs, such as CIS, EFTA, the Pan-Arab Free Trade Agreement (PAFTA), SAFTA, the Caribbean Community and Common Market (CARICOM), and $\mathrm{CACM}$, are quite sensitive to the choice of FE.

We also conduct a sensitivity analysis using the panel data technique with the FE (within) estimator. Column (5) shows that most regional agreements have consistent effects on intra-bloc trade with the results from the PPML estimation. Only EAC and CACM have conflicting effects on intra-bloc trade across the PPML and the FE (within) estimations, because they are sensitive to the treatment of zero trade using the PPML estimator. Interestingly, we also observe that most of the estimated coefficients on the RTAs from the FE (within) estimator are consistent regardless of the FE chosen.

\section{B. Baseline model analyzing the effects of RTAs on extra-bloc trade}

As explained in the previous section, to assess the impacts of RTAs on extra-bloc trade, we have to omit the exporter-year and importer-year FE and estimate Equation (4). The results are summarized in Table 4.

The results in Table 4 provide an overview of the individual RTA trade creation and trade diversion effects. Nine of the 18 plurilateral RTAs have significant trade-promoting effects on their intra-bloc trade, including the Andean Community, COMESA, CIS, EU, EFTA, NAFTA, SAFTA, Mercosur and the Southern African Development Community (SADC). In contrast, significant negative impacts on intra-bloc trade are only noticed for EAC.

It may seem surprising that the coefficient for the intra-bloc trade is negative for a regional agreement since intra-bloc trade tends to increase more than what is predicted by the gravity model following the formation of an RTA. However, Soloaga and Winters (2001), Carrère (2006), Tumbarello (2007), and Kohl (2014) also find a negative sign in the coefficient for intra-bloc trade for several RTAs, including ASEAN, CIS, EFTA, and EU. In our case, the negative coefficient for the EAC intra-bloc trade could be explained by the lack of real effort to promote intra-bloc trade between its African member countries through, for example, reducing tariff barriers or enhancing transportation networks.

Regarding the assessment of the trade creation and trade diversion effects of RTAs in terms 
Table 4. Overview of the estimated impacts of RTAs on extra-bloc trade

\begin{tabular}{|c|c|c|c|c|}
\hline \multirow{2}{*}{ Agreement } & \multicolumn{3}{|c|}{ Estimated coefficients from PPML } & \multirow{2}{*}{ Overall effects } \\
\hline & Intra-bloc & Bloc exports & Bloc imports & \\
\hline$A N D E A N$ & $0.714 * * *$ & -0.161 & $-0.158^{*}$ & $\begin{array}{l}\text { Intra-bloc trade creation }(+104.2 \%) \\
\text { Import diversion }(-14.6 \%)\end{array}$ \\
\hline ANZCERTA & 0.039 & $-0.294 * * *$ & -0.068 & Export diversion $(-25.5 \%)$ \\
\hline$A S E A N$ & 0.012 & 0.137 & 0.093 & No significant effects \\
\hline$C A C M$ & 0.056 & $0.216^{*}$ & $0.372 * * *$ & $\begin{array}{l}\text { Export creation }(+24.1 \%) \\
\text { Import creation }(+45.1 \%)\end{array}$ \\
\hline CAFTADR & -0.001 & -0.083 & -0.099 & No significant effects \\
\hline CARICOM & -0.711 & $-1.279 * * *$ & $-0.448^{* *}$ & $\begin{array}{l}\text { Export diversion }(-72.2 \%) \\
\text { Import diversion }(-36.1 \%)\end{array}$ \\
\hline CEMAC & -0.373 & -0.133 & -0.122 & No significant effects \\
\hline CIS & $1.809 * * *$ & $1.418 * * *$ & $0.695 * * *$ & $\begin{array}{l}\text { Intra-bloc trade creation }(+510.4 \%) \text {; } \\
\text { Export creation }(+312.9 \%) \text {; Import creation }(+100.4 \%)\end{array}$ \\
\hline COMESA & $0.243 *$ & $-0.237 * *$ & $-0.279 * * *$ & $\begin{array}{l}\text { Intra-bloc trade creation }(+27.5 \%) \text {; } \\
\text { Export diversion }(-21.1 \%) \text {; Import diversion }(-24.3 \%)\end{array}$ \\
\hline$E A C$ & $-0.361 * *$ & $-0.610^{* * *}$ & -0.020 & Export diversion $(-45.7 \%)$ \\
\hline EFTA & $0.598 * * *$ & $0.307 * * *$ & $0.276 * * *$ & $\begin{array}{l}\text { Intra-bloc trade creation }(+81.8 \%) \text {; } \\
\text { Export creation }(+35.9 \%) \text {; Import creation }(+31.8 \%)\end{array}$ \\
\hline$E U$ & $0.567 * * *$ & $0.091^{*}$ & -0.045 & $\begin{array}{l}\text { Intra-bloc trade creation }(+76.3 \%) \\
\text { Export creation }(+9.5 \%)\end{array}$ \\
\hline MERCOSUR & $0.605 * * *$ & $-0.134^{*}$ & 0.115 & $\begin{array}{l}\text { Intra-bloc trade creation }(+83.1 \%) \\
\text { Export diversion }(-12.5 \%)\end{array}$ \\
\hline NAFTA & $0.290 * *$ & $-0.195^{* * *}$ & 0.094 & $\begin{array}{l}\text { Intra-bloc trade creation }(33.6 \%) \\
\text { Export diversion }(-17.7 \%)\end{array}$ \\
\hline PAFTA & -0.145 & $-0.164 * *$ & -0.084 & Export diversion $(-15.1 \%)$ \\
\hline$S A D C$ & $0.745 * * *$ & 0.174 & $0.182 *$ & $\begin{array}{l}\text { Intra-bloc trade creation }(+110.6 \%) \\
\text { Import creation }(+20.0 \%)\end{array}$ \\
\hline SAFTA & $0.310^{* * *}$ & $0.369 * * *$ & $0.475 * * *$ & $\begin{array}{l}\text { Intra-bloc trade creation }(+36.3 \%) \text {; } \\
\text { Export creation }(+44.6 \%) \text {; Import creation }(+60.8 \%)\end{array}$ \\
\hline$W A E M U$ & 0.067 & $-0.330^{* * *}$ & $-0.121^{*}$ & $\begin{array}{l}\text { Export diversion }(-28.1 \%) \\
\text { Import diversion }(-11.4 \%)\end{array}$ \\
\hline
\end{tabular}

(Notes) This table provides an overview of the estimated effects of trade agreements on intra-bloc trade and extra-bloc trade. All estimates are obtained by using the PPML estimator with country-pair and year FE. The estimates of the FE and standard errors are omitted for brevity. Appendix 5 shows the full regression output. Respectively, $*$, **, and $* * *$ denote significance at the level of $10 \%, 5 \%$, and $1 \%$.

of the trading bloc exports and imports, there is great heterogeneity in these effects across the regional blocs. A useful approach to analyze these impacts is to group the RTAs based on their geographic area or levels of development.

Trade agreements involving European countries, including EU, EFTA, and CIS, witness export creation by means of significant positive coefficients on bloc exports along with an increase in their intra-bloc trade. Import creation is also observed in the cases of EFTA and CIS. Interestingly, we find that European RTAs have had a strong trade-promoting impact on 
both intra-bloc trade and extra-bloc trade. For instance, intra-EU27 trade is $76.3 \%$ above the levels that are predicted by the gravity model along with a propensity to export to non-members increasing by $9.5 \%$ on average over the period of 1960 2014.

Our findings in terms of the EU27 effect are in line with the results from Soloaga and Winters (2001), Carrère (2006) and Trotignon (2010) that indicate export creation for the EU. The EU does not have any significant effect on its bloc imports, which is akin to the findings of Soloaga and Winters (2001). Additionally, we do not find any evidence that the regional integration of EU members negatively impacts EU exports and imports to/from the rest of the world, thus imposing costs on non-members. Specifically, our findings cover all of the enlargement processes of the EU from EU9 to EU27. Nonetheless, our results of the effects on EU extra-bloc trade are quite different from the findings of Frankel (1997) and Sapir (1998), which do not cover the recent expansion of the EU.

In the case of EFTA, its extra-bloc trade patterns reflect its openness toward European neighbors, especially its former members that joined the EU during the 80s and 90s. This result is also in line with Soloaga and Winters (2001).

Note that CIS experiences an excessively high level of trade creation effects in terms of both intra-bloc trade and extra-bloc trade. This might be explained first by the strong trade ties between CIS members, which are former members of the Soviet Union. Second, as argued earlier, CIS intra-bloc effects are very sensitive to the set of country-pair and year FE. Therefore, we do not take into account the effects of CIS on its members' intra-bloc and extra-bloc trade at the further stage of our analysis.

Turning to the RTAs formed by countries in America, most plurilateral trade agreements were found to have extra-bloc trade diversion effects in terms of bloc exports or imports despite the members' levels of economic development. We show a negative propensity to export to the rest of the world for NAFTA and Mercosur countries, with an average decline of $17.7 \%$ and of $12.5 \%$, respectively. This result is in line with the findings of Soloaga and Winters (2001) concerning both RTAs and of Trotignon (2010) with regard to NAFTA but are contradictory to the findings of Carrère (2006). The latter study revealed significant import diversion and negligible effects on bloc exports for these two trading blocs.

In addition, an import diversion effect is found for Andean, which is also found by Soloaga and Winters (2001) and Carrère (2006). We also obtain export and import diversion effects for CARICOM. Only CACM shows a tendency to increase extra-bloc exports and imports with the rest of the world, which is in line with the findings of Trotignon (2010). We do not find any trade impacts for the Dominican Republic-Central America Free Trade Agreement (CAFTA-DR) in the setting of Equation (4), since it entered into force only recently (in 2006).

Turning next to the RTAs in Asia-Pacific, the SAFTA and ASEAN have positive coefficient estimates for extra-bloc trade in terms of exports and imports, but the coefficient estimates 
are insignificant in the case of ASEAN. This result may suggest that the trade patterns of their member countries are actively oriented toward trade with the rest of the world. They possess huge consumer markets for goods imported from the rest of the world as well as large global markets for their potential exports from different sectors, such as agriculture, the textiles and apparel industry, the electronics industry, among others.

On the other hand, PAFTA demonstrates export diversion. However, since several of the countries participating in PAFTA are member countries of the Organization of the Petroleum Exporting Countries (OPEC), like Saudi Arabia, Kuwait, Qatar, and the United Arab Emirates, these countries' petroleum export policies likely induced complex impacts on the trade patterns of PAFTA. ANZCERTA also shows an export diversion effect at the expense of the rest of the world, since Australia and New Zealand are quite distant from other countries.

For African RTAs, we study the effects of several agreements, including COMESA, SADC, and EAC in South East Africa, the West African Economic and Monetary Union (WAEMU) and the Economic and Monetary Community of Central Africa (CEMAC). Note that there is a complex network of RTAs in Africa, with several overlapping trading blocs that have been established by the same trading partners ${ }^{12}$. We find that there is no significant trade-creating effect in terms of intra-bloc trade for several African RTAs, except for COMESA and SADC. Most African RTAs have a negative propensity to export and import with the rest of the world, especially WAEMU and COMESA. The findings are likely to reflect the strong connection among African countries in East Africa and among former French colonies in West Africa through a tendency to trade with member countries, which is detrimental to non-members. Nonetheless, COMESA is the only RTA that is experiencing an increase in intra-bloc trade; however it is entirely offset by a lower propensity to export and import. In contrast, an import creation effect is only found for SADC, which is likely driven mainly by the dynamics of imports by South Africa (a BRICS member) from the rest of the world.

In short, four main findings emerge from our study. First, intra-bloc trade creation effects are found for most plurilateral RTAs. There are indeed increases in trade between member countries in the wake of the establishment of several RTAs. Second, the impacts of regional agreements on extra-bloc trade are heterogeneous. Export and import diversion effects are significant in many RTAs based in America and Africa, regardless of whether they are formed by developed countries or developing countries. In contrast, there are more export and import creations resulting from the formation of RTAs in Europe and Asia. Third, when the impact of an RTA on extra-bloc trade in terms of both bloc exports and imports is significant, we do not discover any RTA that has a contradictory sign of the estimated coefficients on the RTA's exports and imports. This suggests that there is no evidence that export diversion effect

12) For instance, Tanzania has joined all of the three RTAs in South East Africa (COMESA, SADC, and EAC), and Madagascar has also participated in COMESA and SADC. 
couples with the import creation effect and vice versa. Finally, the estimated impacts of RTAs on international trade are still very consistent and comparable with the findings from the literature when zero trade flows are taken into account by using the PPML estimator.

\section{Robustness Checks and Extension}

\section{A. Adjustment in trade flows}

Since bilateral trade flows need time to adjust to changes in trade policies or trade costs, our first robustness check uses panel data with 3-year intervals in preference to data compiled over consecutive years, as proposed by Baier and Bergstrand (2007), Olivero and Yotov (2012), Kohl (2014) and Anderson and Yotov (2016).

The results for the adjustment in trade flows from the specification using only RTA intra-bloc trade dummies are presented in Panel B, Table 3. We find that eleven of the 18 plurilateral RTAs have consistent trade-promoting effects in terms of intra-bloc trade, as obtained by the PPML estimator. Only CAFTA-DR and PAFTA have negligible effects on members' trade instead of significant impacts resulting from the estimation based on a dataset built over consecutive years. In addition, there are then only two RTAs with conflicting effects on intra-bloc trade between the PPML and the FE (within) estimations (EAC and CACM).

Interestingly, Asian RTAs, such as ASEAN and SAFTA, continue to show insignificant impacts on intra-bloc trade in the results of the PPML regression (Column (6), Table 3) and significant negative impact in the results from the FE (within) estimation (Column (7), Table $3)$. This reflects their long implementation period in terms of trade liberalization schedules ${ }^{13}$ ). ASEAN has implemented tariff concessions for over 26 years (from 1992 to 2018), while the SAFTA has an implementation period of over ten years (from 2006 to 2016). This means that ASEAN members have gradually lowered their trade barriers (both tariff and non-tariff barriers) for goods coming from other members. Thus, the slow decrease in trade barriers within ASEAN does not generate substantial impacts on their intra-bloc trade.

Regarding the effects of RTAs on both intra-bloc trade and extra-bloc trade that are presented in Figure 4, the gravity estimates that are obtained with 3-year intervals deliver consistent results with regard to the baseline results built on consecutive years. Thus, the effects of individual RTAs on intra-bloc trade and extra-bloc trade in terms of exports and imports are very similar

13) Each RTA is subject to a different liberalization procedure and schedule. In some RTAs, the liberalization of intra-bloc trade takes place upon the date of entry into force of the trade agreement. In this study, this date is used to define whether the dummies for the RTA take the value of 1 or 0 . More common for RTAs is a phased implementation of tariff concessions over a period. The WTO's data on RTAs determines that the implementation period for a given RTA is the date of final implementation of tariff eliminations undertaken by the slowest liberalizing member. 
for 14 of the RTAs. Only a few additional effects are found, such as import diversion for CAFTA-DR and export creation for SADC.

Figure 4. Overview of the effects of RTAs on extra-bloc trade based on different intervals panel data

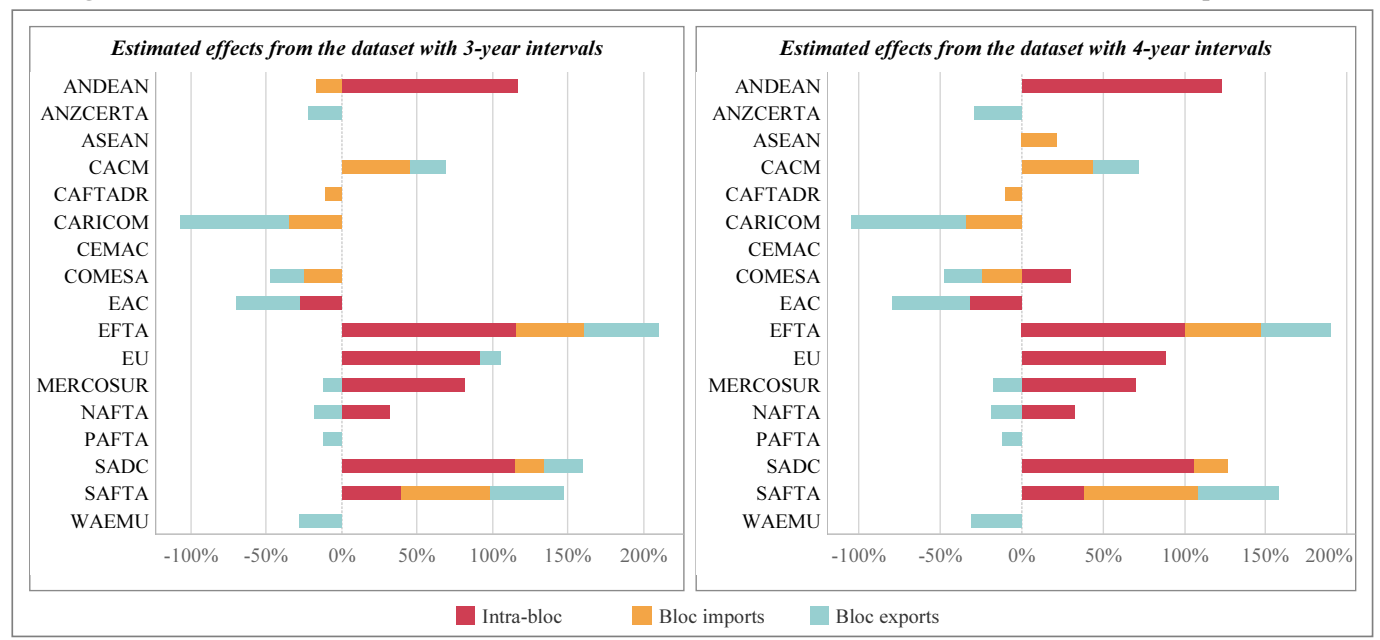

(Notes) Only estimates for the effects of RTAs that are statistically significant at least at the level of $10 \%$ are shown in this figure. Results are estimated using the PPML estimator with country-pair and year FE. The vertical axis reports the RTAs. The effects of RTAs on trade flows are indicated on the horizontal axis. The trade creation impact is represented by a positive effect, whereas the trade diversion impact is indicated by a negative effect. Appendix 5 shows the full regression output.

(Source) Author's calculations.

We also experiment with data composed of 4-year gaps and find that the similarity in the results always holds for most of the RTAs included in this study. Surprisingly, the import creation effect is indicated for ASEAN, as discussed, these member countries have a propensity to exchange goods with the rest of the world. This finding is consistent with Soloaga and Winters (2001) and Carrère (2006). In addition, we no longer find any significant extra-bloc trade effects for the EU.

Moreover and as expected, the consistency in our results covering 3-year and 4-year intervals data is in line with the work of Olivero and Yotov (2012). They find that a dataset with 3-year, 4-year or 5-year intervals provides similar results for the estimates of gravity variables in terms of magnitudes, significance, and signs.

\section{B. Phased-in period of regional trading blocs}

As regional agreements potentially have a phase-in period, we employ lagged RTAs variables to account for these dynamic effects of RTAs. Following the proposition of Baier and Bergstrand (2007), our second robustness check includes three- and six-year lags of the set of RTA variables in our estimation. Thus, our gravity specification becomes the following: 


$$
\begin{aligned}
& X_{i j t}=\exp \left[\beta_{0}+\beta_{1} \ln \left(G D P_{i t}\right)+\beta_{2} \ln \left(G D P_{j t}\right)+\beta_{3} \ln \left(D I S T_{i j}\right)+\beta_{4}\left(L A N G_{i j}\right)+\beta_{5}\left(C O N T I G_{i j}\right)\right. \\
& +\alpha_{\text {Intra }}^{k}\left(R T A^{k} \text { Intra }_{i j t}\right)+\alpha_{X}^{k}\left(R T A^{k}{ }_{-} X_{i j t}\right)+\alpha_{M}^{k}\left(R T A^{k}{ }_{-} M_{i j t}\right) \\
& +\sigma_{\text {Intra }}^{k}\left(R T A^{k} \text { Intra }_{i j t-3}\right)+\sigma_{X}^{k}\left(R T A^{k} X_{i j t-3}\right)+\sigma_{M}^{k}\left(R T A^{k}{ }_{-} M_{i j t-3}\right) \\
& \left.+\theta_{\text {Intra }}^{k}\left(R T A^{k} \text { Intra }_{i j t-6}\right)+\theta_{X}^{k}\left(R T A^{k} X_{i j t-6}\right)+\theta_{M}^{k}\left(R T A^{k}{ }_{i j t-6}\right)+\lambda_{i j}+\vartheta_{t}\right]+\varepsilon_{i j t}
\end{aligned}
$$

Figure 5 summarizes the estimated results from Specification (5) and shows the total average treatment effect (ATE) in terms of intra-bloc trade, bloc exports and imports, respectively. Total ATE is the sum of the statistically significant RTA estimated coefficients following Baier, Bergstrand, and Feng (2014). First, we find that trade agreements continue to yield effects on the members' trade flows up to six years after they have entered into force. Fourteen of the 18 RTAs show consistent overall effects on intra-bloc trade and extra-bloc trade regardless of the inclusion of one or two lagged variables; the exceptions are EU, PAFTA, and EAC. This suggests that including 3-year and 6-year lags leads to variation in the effects of these RTAs on their extra-bloc trade, e.g., no more import diversion for the EU and EAC after six years and an import creation effect for PAFTA in place of import diversion after six years. The WAEMU is the only trading bloc that does not experience any significant effects on members' trade.

Moreover, our results including RTA lagged variables are consistent with our baseline model in the previous section. We do not find that any RTAs have conflicting trade effects with the specification excluding the lagged terms. Interestingly, the addition of the RTA lagged variables leads to an emergence of RTA phased-in effects that cannot be obtained at the year of entry but instead, are obtained after a certain period of time. Thus, intra-bloc trade creation for ASEAN, ANZCERTA, and COMESA appears after three years of entry into force; import diversion also emerges for CAFTA-DR, PAFTA, and EAC in the specification with the RTA lagged terms. 
Figure 5. Total average treatment effect of RTAs with phased-in period

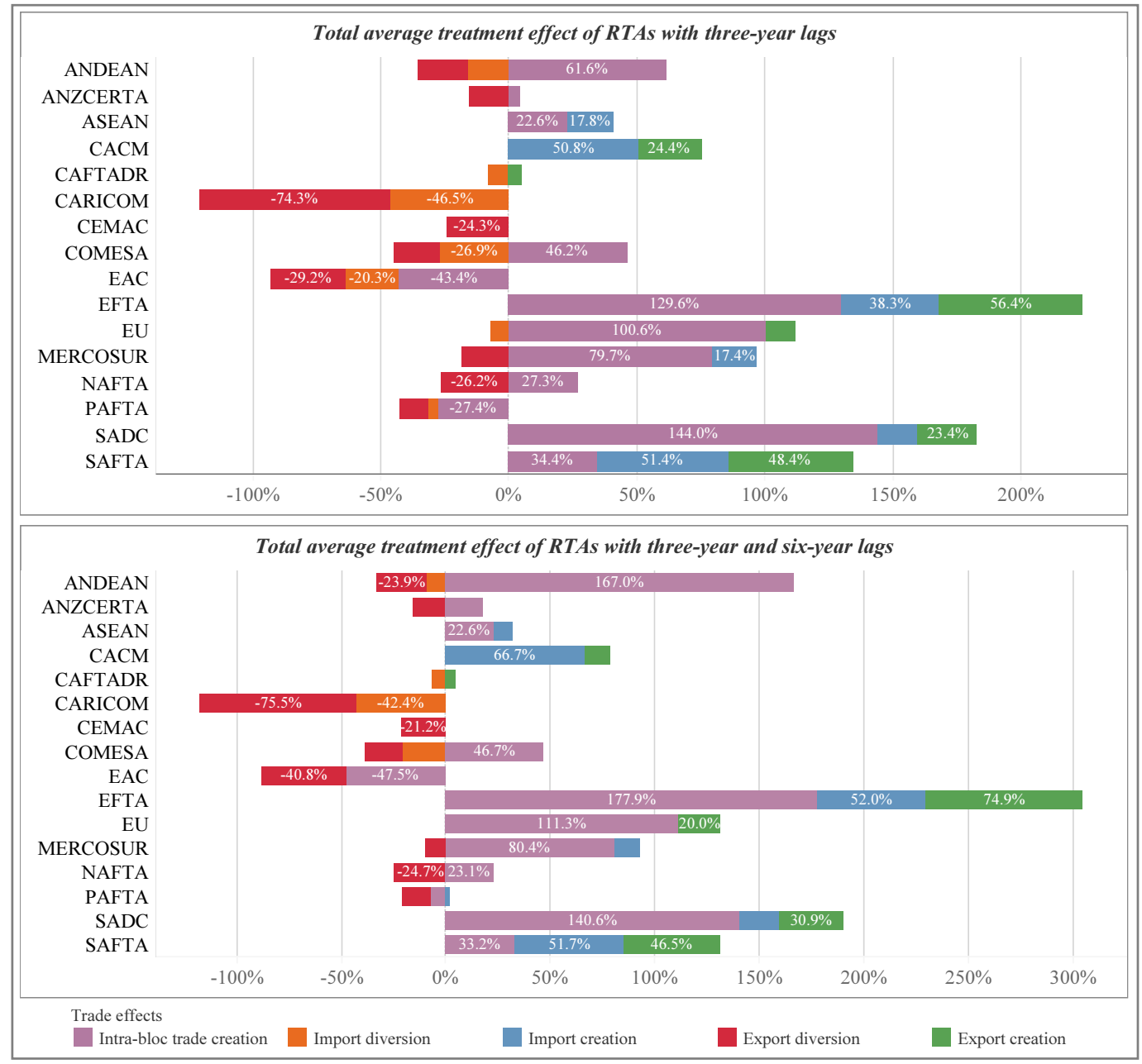

(Notes) Only estimates for the effects of RTAs that are statistically significant at least at the level of $10 \%$ are shown in this figure. Results are based on the data with 3-year intervals and estimated using the PPML estimator with country-pair and year FE. The vertical axis reports the RTAs. The effects of RTAs on trade flows are indicated on the horizontal axis. The trade creation impact is represented by a positive effect, whereas the trade diversion impact is indicated by a negative effect. The full regression output is available upon request.

(Source) Author's calculations.

\section{Effects of RTAs on individual member countries}

For this extension to the analysis, we take into account the effects of RTAs on each member country individually. Countries involved in an RTA may experience different impacts on their intra-bloc trade following the introduction of the trade agreement because they differ substantially in economic and geographic characteristics (i.e., GDP, trade openness, distance to the rest of the world, etc.). Thus, we expect heterogeneous intra-bloc trade effects of RTAs on an individual member. 
Based on our preferred gravity Equation (3), we add a country dummy as suggested by Herderschee and Qiao (2007) and Soete and Van Hove (2017) to estimate this individual effect for member countries. Equation (3) then becomes the following:

$$
\begin{aligned}
X_{i j t} & =\exp \left[\beta_{0}+\beta_{1} \ln \left(G D P_{i t}\right)+\beta_{2} \ln \left(G D P_{j t}\right)+\beta_{3} \ln \left(D I S T_{i j}\right)+\beta_{4}\left(L A N G_{i j}\right)+\beta_{5}\left(\text { CONTIG }_{i j}\right)\right. \\
& \left.+\alpha_{\text {Intra }}^{k}\left(R T A^{k} \text { Intra }_{i j t}\right) \times C_{j t}+\gamma_{i t}+\eta_{j t}+\lambda_{i j}\right]+\varepsilon_{i j t}
\end{aligned}
$$

Here, we employ an importer country dummy $\left(C_{j t}\right)$ to better acquire the trade-promoting effects of an RTA with regard to intra-bloc imports on a member country by means of a reduction in the importer's tariffs and other non-tariff barriers. Likewise, we use an exporter country dummy $\left(C_{i t}\right)$ to obtain the effects of a trade agreement concerning intra-bloc exports. However, we cannot include both dummies in the same equation due to the problem of collinearity.

Figure 6 presents results that involve six plurilateral RTAs that have an important share of intra-bloc trade in their total trade flows and a high level of depth of integration. These RTAs tend to increase the intra-bloc trade of their member countries; however, these trade-promoting effects are not significant nor are they experienced by every member. We find that only the Andean Community increases the intra-bloc imports and exports among all of its members. The EU is found to significantly increase the intra-bloc trade in terms of both imports and exports for only its 17 members. Interestingly, ASEAN boosts intra-bloc imports in the case of Indonesia and Myanmar but decreases imports from other ASEAN members (i.e., Cambodia, Singapore, and Malaysia). The Philippines experiences a significant increase in its intra-bloc exports at the expense of Malaysia, Cambodia, and Vietnam. Moreover, most countries that join the ASEAN do not experience any positive effects of this trade agreement on trade flows.

Only the United States experiences an increase in its intra-bloc imports within NAFTA. Nonetheless, NAFTA boosts the intra-bloc exports of Canada and Mexico. For Mercosur, almost all of their member countries experience significant trade-promoting effects from their respective regional agreements, especially Argentina and Brazil, which obtain a more pronounced increase in their intra-bloc trade than Paraguay and Uruguay.

In addition, we obtain great heterogeneity in the magnitude of the effects of RTAs on intra-bloc imports and exports for most of the plurilateral RTAs, such as the EU, WAEMU, and Andean Community. For instance, the EU increases imports from other members by approximately $250 \%$ for Romania and more than $210 \%$ for Estonia but only by $30 \%$ for Austria. Our findings suggest that countries taking part in the recent expansion of the EU (i.e., Romania, Poland, and Hungary) experience a more prominent impact on trade from the EU in terms of intra-bloc imports and exports than other EU member countries. 
Figure 6. Effects of RTAs on individual member countries

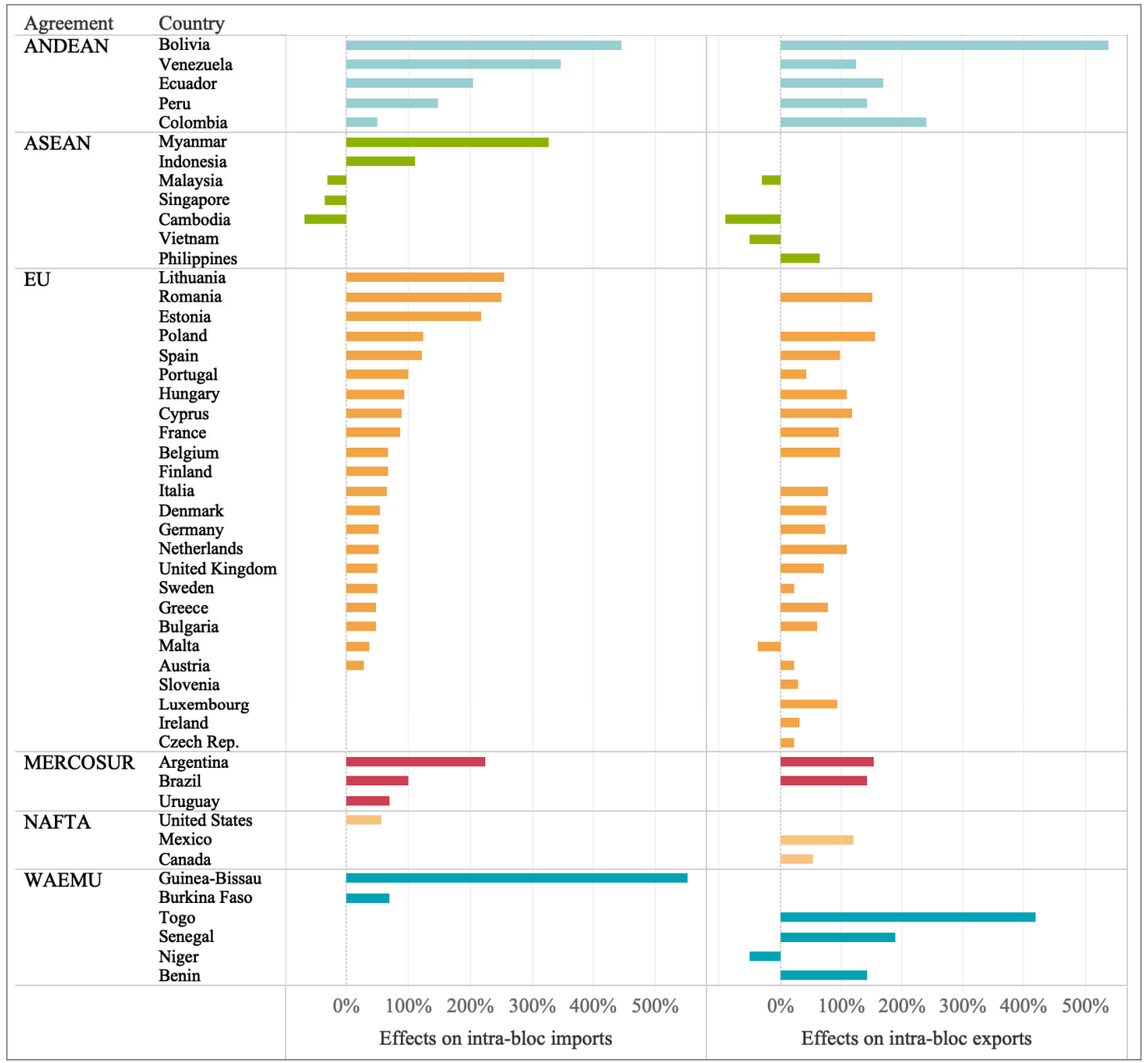

(Notes) Only estimates for the effects of RTAs on their members' trade that are statistically significant at least at the level of $10 \%$ are shown in this figure. Results are based on the data with 3-year intervals and estimated using the PPML estimator with exporter-year, importer-year and country-pair FE. The full regression output is available upon request.

(Source) Author's calculations.

\section{Conclusions}

This paper revisits the ex-post effects of RTAs on member countries' trade by applying some of the most up-to-date methodological improvements in the empirical literature on trade. By adopting the PPML estimator and a theoretically-motivated FE gravity model, we find significant intra-bloc trade creation for most of the plurilateral RTAs included in our analysis, such as the EU, Andean, NAFTA, and Mercosur. The Asian RTAs, such as ASEAN and SAFTA, 
do not appear to have significant impacts on their intra-bloc trade among members immediately upon their entry into force. It is because these RTAs have a long implementation period concerning trade liberalization procedures. The sensitivity analyses consistently displayed that the trade-promoting role is robust for more than half of the 18 RTAs across various specifications, allowing for adjustments of trade flows and the phased-in effects of trade agreements.

This finding has important implications for future trade policy. It would be interesting to assess the impacts of new RTAs based on their own trade liberalization schedules. Some trading blocs expect a longer period of time during which tariffs are phased out and removed to generate a true trade-creating effect for members' trade. Furthermore, member countries, especially the developing economies in RTAs, want to quickly reduce tariffs on imports from other members and expedite the phase-in period. In any case improvements in infrastructure should be continued within various RTAs formed by developing countries (e.g., the RTAs located in Africa) to facilitate trade links among members.

Other interesting findings are revealed with regard to RTAs' impacts on bloc exports and imports. The impacts of regional agreements on extra-bloc trade are heterogeneous. However, a majority of the RTAs show evidence of trade diversion effects in terms of extra-bloc trade. In particular, we observed significant export and import diversion in many RTAs based in America and Africa, despite the nature of the RTAs as agreements formed by developed countries or developing countries, such as NAFTA, Mercosur, Andean, WAEMU, COMESA, and EAC. In contrast, export and import creations are more prominent for RTAs in Europe and Asia.

Interestingly, our results, featuring the increase in intra-bloc trade coupled with trade diversion in terms of extra-bloc trade for most RTAs are in line with previous studies, such as Soloaga and Winters (2001) and Carrère (2006). Moreover, these results are consistent across different specifications, including lagging RTA variables by three years or six years. For most RTAs, the effects of trade diversions on extra-bloc trade are still predominant six years after their entry into force. Our findings suggest that the propensity of regional integration around the world has improved the performance of intra-bloc trade for many RTAs; nonetheless, it is detrimental to the rest of the world. Hence, this result appears plausible in the light of the upsurge in RTAs over the past two decades and the failure of the Doha Round of the WTO, which aims to improve the multilateral trading system.

It seems that African and American trading blocs, which are formed in the same geographical areas, enhances the coherence between them in terms of tariff cuts and the setting up of more transparent and less complex rules of origin. This mechanism would be useful to limit the welfare losses that emerge from trade diversion. In addition, the WTO might have a pivotal contribution toward "open regionalism" and the multi-lateralization of existing plurilateral trading blocs. The WTO could coordinate RTAs and narrow down the differences in the collections 
of rules and margins of preference across those trading blocs, as advocated by Baldwin and Thornton (2008).

Our results also show that a plurilateral RTA can have very heterogeneous impacts on its member countries. This suggests that the governments involved in trade deals may not systematically seek homogeneous effects for all partners. Instead, the extent of the trade-creating effect of an RTA on member countries is likely to be driven by the gains or losses from their own trade policies, i.e., from specialization based on differences in resource endowments or from intra-industry trade based on scale economies and product differentiation among the member countries. Thus, policymakers need to be cautious in making use of RTAs as an indisputable tool to promote trade liberalization and spur economic benefits to the global trading system.

\section{References}

Acharya, Rohini. (2016). Regional Trade Agreements and the Multilateral Trading System. Cambridge: Cambridge University Press.

Aitken, Norman D. (1973). "The effect of the EEC and EFTA on European trade: A temporal cross-section analysis." The American Economic Review 63, no. 5, 881-892.

Anderson, James E. (1979). "A theoretical foundation for the gravity Equation." The American Economic Review 69, no. 1, 106-116.

Anderson, James E., Mario Larch, and Yoto V. Yotov. (2018). "GEPPML: General equilibrium analysis with PPML." The World Economy 41, no. 10, 2750-2782.

Anderson, James E., and Eric van Wincoop. (2003). "Gravity with Gravitas: A solution to the border puzzle." The American Economic Review 93, no. 1, 170-192.

Anderson, James E., and Yoto V. Yotov. (2012). Gold Standard Gravity. NBER Working Paper No. 17835, National Bureau of Economic Research, Cambridge, MA.

Anderson, James E., and Yoto V. Yotov. (2016). "Terms of trade and global efficiency effects of free trade agreements, 1990-2002." Journal of International Economics 99, no. c, 279-298.

Baier, Scott L., and Jeffrey H. Bergstrand. (2001). "The growth of world trade: tariffs, transport costs, and income similarity." Journal of International Economics 53, no. 1, 1-27.

Baier, Scott L., and Jeffrey H. Bergstrand. (2007). "Do free trade agreements actually increase members' international trade?" Journal of International Economics 71, no. 1, 72-95.

Baier, Scott L., Jeffrey H. Bergstrand, and Michael Feng. (2014). "Economic integration agreements and the margins of international trade." Journal of International Economics 93, no. 2, 339-350.

Balassa, Bela. (1961). "Towards a theory of economic integrational." Kyklos 14, no. 1, 1-17.

Baldwin, Richard E. (1993). A Domino Theory of Regionalism. NBER Working Paper No. 4465, National Bureau of Economic Research, Cambridge, MA.

Baldwin, Richard E. (2004). "Stepping stones or building blocs? Regional and multilateral integration." Unpublished Manuscript, Graduate Institute of International Studies, Geneva, Switzerland. 
Baldwin, Richard E., and Daria Taglioni. (2006). Gravity for Dummies and Dummies for Gravity Equations. NBER Working Paper No. 12516, National Bureau of Economic Research, Cambridge, MA.

Baldwin, Richard E., and Philip Thornton. (2008). Multilateralising Regionalism: Ideas for a WTO Action Plan on Regionalism. London: Centre for Economic Policy Research.

Bayoumi, Tamim, and Barry Eichengreen. (1997). "Is regionalism simply a diversion? Evidence from the evolution of the EC and EFTA." In Regionalism vs. Multilateral Arrangements, edited by Takatoshi Ito and Anne O Krueger. Chicago: The University of Chicago Press.

Bergstrand, Jeffrey H. (1985). "The gravity equation in international trade: Some microeconomic foundations and empirical evidence." The Review of Economics and Statistics 67, no. 3, 474-481.

Bergstrand, Jeffrey H. (1989). "The generalized gravity equation, monopolistic competition, and the factorproportions theory in international trade." The Review of Economics and Statistics 71, no. 1, 143-153.

Bhagwati, Jagdish. (1991). The World Trading System at Risk. Princeton, NJ: Princeton University Press.

Bhagwati, Jagdish. (1995). "U.S. trade policy: The infatuation with free trade areas." In The Dangerous Drift to Preferential Trade Agreements, edited by J. Bhagwati and A. Krueger. Washington, D.C.: American Enterprise Institute for Public Policy Research.

Bhagwati, Jagdish. (2008). Termites in the Trading System: How Preferential Agreements Undermine Free Trade. Oxford: Oxford University Press.

Brada, Josef C., and José A. Méndez. (1985). "Economic integration among developed, developing and centrally planned economies: A comparative analysis." The Review of Economics and Statistics 67, no. 4 , 549-556.

Brun, Jean-Francois, Celine Carrère, Patrick Guillaumont, and Jaime de Melo. (2005). "Has distance died? Evidence from a panel gravity model." World Bank Economic Review 19, no. 1, 99-119.

Burger, Martijn, Frank van Oort, and Gert-Jan Linders. (2009). "On the specification of the gravity model of trade: Zeros, excess zeros and zero-inflated estimation.” Spatial Economic Analysis 4, no. 2, 167-190.

Bussière, Matthieu, Jarko Fidrmuc, and Bernd Schnatz. (2005). Trade Integration of Central and Eastern European Countries: Lessons from a Gravity Model. Working Paper No. 105, Oesterreichische Nationalbank (Austrian Central Bank), Vienna, Austria.

Carrère, Celine. (2006). "Revisiting the effects of regional trade agreements on trade flows with proper specification of the gravity model." European Economic Review 50, no. 2, 223-247.

Cheng, I-hui, and Howard J. Wall. (2005). "Controlling for heterogeneity in gravity models of trade and integration." Federal Reserve Bank of St. Louis Review 87, no. 1, 49-63.

Deardorff, Alan. (1998). "Does gravity work in a neoclassical world?" In The Regionalization of the World Economy, edited by Jeffrey A Frankel. Chicago: The University of Chicago Press.

Endoh, Masahiro. (1999). "Trade creation and trade diversion in the EEC, the LAFTA and the CMEA: 1960-1994.” Applied Economics, 31, no. 2, 207-216.

Feenstra, Robert. (2004). Advanced International Trade: Theory and Evidence. Princeton, NJ: Princeton University Press.

Felbermayr, Gabriel J., and Wilhelm Kohler. (2006). "Exploring the intensive and extensive margins of world trade." Review of World Economics 142, no. 4, 642-674.

Filippini, Carlo, and Vasco Molini. (2003). "The determinants of East Asian trade flows: A gravity equation 
approach." Journal of Asian Economics 14, no. 5, 695-711.

Frankel, Jeffrey A. (1997). Regional Trading Blocs in the World Economic System. Washington, D.C.: Peterson Institute for International Economics.

Frankel, Jeffrey A., Ernesto Stein, and Shang-jin Wei. (1995). "Trading blocs and the americas: The natural, the unnatural, and the super-natural." Journal of Development Economics 47, no. 1, 61-95.

Freund, Caroline, and Emanuel Ornelas. (2010). Regional Trade Agreements. World Bank Policy Research Working Paper No. 5314, World Bank, Washington, D.C.

Head, Keith, and Thierry Mayer. (2013). Gravity Equations: Workhorse, Toolkit, and Cookbook. CEPII Working Paper No. 2013-27 September, CEPII Research Center, Paris, France.

Head, Keith, Thierry Mayer, and John Ries. (2010). "The erosion of colonial trade linkages after independence." Journal of International Economics 81, no. 1, 1-14.

Helpman, Elhanan, and Paul Krugman. (1985). Market Structure and Foreign Trade. Cambridge, MA: MIT Press.

Helpman, Elhanan, Marc Melitz, and Yona Rubinstein. (2008). "Estimating trade flows: Trading partners and trading volumes." The Quarterly Journal of Economics 123, no. 2, 441-487.

Herderschee, Johannes, and Zhaogang Qiao. (2007). Impact of Intra-European Trade Agreements, 19902005: Policy Implications for the Western Balkans and Ukraine. IMF Working Paper No. WP/07/126, International Monetary Fund, Washington, D.C.

Johnson, Harry G. (1960). "The economic theory of customs unions." Pakistan Economic Review 10, 14-30.

Kemp, Murray C., and Henry Y. Wan. (1976). "An elementary proposition concerning the formation of customs unions." Journal of International Economics 6, no. 1, 95-97.

Kimura, Fukunari, and Mitsuyo Ando. (2005). "Two-dimensional fragmentation in East Asia: Conceptual framework and empirics." International Review of Economics and Finance 14(3 SPEC. ISS.), 317-348.

Kohl, Tristan. (2014). "Do we really know that trade agreements increase trade?" Review of World Economics, 150, no. 3, 443-469.

Krugman, Paul. (1991). "The move toward free trade zones." Economic Review Nov, 5-25.

Larch, Mario, Joschka Wanner, Yoto V. Yotov, and Thomas Zylkin. (2017). The Currency Union Effect: A PPML Re-Assessment with High-Dimensional Fixed Effects. School of Economics Working Paper Series 2017-7, LeBow College of Business, Drexel University.

Lawrence, Robert Z. (1996). Regionalism, Multilateralism, and Deeper Integration. Washington, D.C.: Brookings Institution.

Lee, Jong-Wha, and Innwon Park. (2005). "Free trade areas in East Asia: Discriminatory or non-discriminatory?" The World Economy 28, no. 1, 21-48.

Lee, Jong-Wha, and Phillip Swagel. (1997). "Trade barriers and trade flows across countries and industries." Review of Economics and Statistics 79, no. 3, 372-382.

Lipsey, Richard G. (1970). The Theory of Customs Unions: A General Equilibrium Analysis. L.S.E. Research Monographs. London: Weidenfeld \& Nicolson.

Magee, Christopher. (2003). "Endogenous preferential trade agreements: An empirical analysis." The B.E. Journal of Economic Analysis \& Policy 2, no. 1, 1-19. 
Magee, Christopher. (2008). "New measures of trade creation and trade diversion." Journal of International Economics 75, no. 2, 349-362.

Martin, Will, and Cong Pham. (2015). Estimating the Gravity Model When Zero Trade Flows Are Frequent and Economically Determined. Policy Research Working Paper No. WPS 7308, World Bank, Washington, D.C.

Meade, James E. (1955). The Theory of Customs Unions. Amsterdam: North-Holland.

Olivero, María P., and Yoto V. Yotov. (2012). "Dynamic gravity: endogenous country size and asset accumulation." Canadian Journal of Economics/Revue Canadienne d'économique 45, no. 1, 64-92.

Santos Silva, J. M., and Silvana Tenreyro. (2006). "The log of gravity." The Review of Economics and Statistics, 88, no. 4 641-658.

Sapir, André. (1998). "The political economy of EC regionalism.” European Economic Review 42, no. 3-5, 717-732.

Soete, Sophie, and Jan Van Hove. (2017). "Dissecting the trade effects of Europe's economic integration agreements." Journal of Economic Integration 32, no. 1, 193-243.

Soloaga, Isidro, and L. Alan Winters. (2001). "Regionalism in the nineties: What effect on trade?" The North American Journal of Economics and Finance 12, no. 1, 1-29.

Summers, Lawrence H. (1991). "Regionalism and the world trading system." Policy Implications of Trade and Currency Zones, 295-301.

Tinbergen, Jan. (1962). Shaping the World Economy. New York: The Twentieth Century Fund.

Trefler, Daniel. (1993). "Trade liberalization and the theory of endogenous protection: An econometric study of U.S. import policy." Journal of Political Economy 101, no. 1, 138-160.

Trotignon, Jerome. (2010). "Does regional integration promote the multilateralization of trade flows?: A gravity model using panel data." Journal of Economic Integration 25, no. 2, 223-251.

Tumbarello, Patrizia. (2007). Are Regional Trade Agreements in Asia Stumbling or Building Blocks? Implications for the Mekong-3 Countries. IMF Working Paper No. 07/53, International Monetary Fund, Washington, D.C.

Viner, Jacob. (1950). The Customs Union Issue. Studies in the Administration of International Law and Organization. New York: Carnegie Endowment for International Peace.

Westerlund, Joakim, and Fredrik Wilhelmsson. (2011). "Estimating the gravity model without gravity using panel data." Applied Economics 43, no. 6, 641-649.

World Trade Organization. (1995). Analytical Index: Guide to GATT Law and Practice, Volume 2. Geneva: World Trade Organization.

World Trade Organization. (2019). "Regional Trade Agreements Information System (RTA-IS)." Accessed January 15. http://rtais.wto.org/UI/PublicMaintainRTAHome.aspx. 


\section{Appendix 1. List of countries in the dataset}

\begin{tabular}{|c|c|c|c|}
\hline Albania & Dominica & Lao & Sao Tome and Principe \\
\hline Algeria & Dominican Republic & Latvia & Saudi Arabia \\
\hline Angola & Ecuador & Lebanon & Senegal \\
\hline Argentina & Egypt & Lithuania & Seychelles \\
\hline Armenia & El Salvador & Luxembourg & Sierra Leone \\
\hline Australia & Equatorial Guinea & Macao & Singapore \\
\hline Austria & Estonia & Macedonia & Slovakia \\
\hline Azerbaijan & Ethiopia & Madagascar & Slovenia \\
\hline Bahamas & Fiji & Malawi & Somalia \\
\hline Bahrain & Finland & Malaysia & South Africa \\
\hline Bangladesh & France & Mali & Spain \\
\hline Barbados & Gabon & Malta & Sri Lanka \\
\hline Belarus & Gambia & Mauritania & St. Kitts and Nevis \\
\hline Belgium & Georgia & Mauritius & St. Lucia \\
\hline Belize & Germany & Mexico & St. Vincent and the Grenadines \\
\hline Benin & Ghana & Mongolia & Sudan \\
\hline Bolivia & Greece & Morocco & Suriname \\
\hline Bosnia and Herzegovina & Grenada & Mozambique & Sweden \\
\hline Brazil & Guatemala & Myanmar & Switzerland \\
\hline Brunei Darussalam & Guinea & Nepal & Tajikistan \\
\hline Bulgaria & Guinea-Bissau & Netherlands & Tanzania \\
\hline Burkina Faso & Guyana & New Zealand & Thailand \\
\hline Burundi & Haiti & Nicaragua & Togo \\
\hline Cambodia & Honduras & Niger & Tonga \\
\hline Cameroon & Hong Kong & Nigeria & Trinidad and Tobago \\
\hline Canada & Hungary & Norway & Tunisia \\
\hline Cabo Verde & Iceland & Oman & Turkey \\
\hline Central African Republic & India & Pakistan & Turkmenistan \\
\hline Chad & Indonesia & Panama & Uganda \\
\hline Chile & Iran & Papua New Guinea & Ukraine \\
\hline China & Ireland & Paraguay & United Arab Emirates \\
\hline Colombia & Israel & Peru & United Kingdom \\
\hline Comoros & Italy & Philippines & United States \\
\hline Congo, Republic of & Jamaica & Poland & Uruguay \\
\hline Costa Rica & Japan & Portugal & Uzbekistan \\
\hline Côte d'Ivoire & Jordan & Qatar & Vanuatu \\
\hline Cyprus & Kazakhstan & Romania & Venezuela \\
\hline Czech Republic & Kenya & Russian Federation & Vietnam \\
\hline Denmark & Korea, Republic of & Rwanda & Zambia \\
\hline Djibouti & Kuwait & Samoa & Zimbabwe \\
\hline
\end{tabular}




\section{Appendix 2. List of RTAs and members included in the estimation}

\begin{tabular}{|c|c|c|}
\hline Trade agreement & Type & Member countries \\
\hline Andean Community & $\mathrm{CU}$ & $\begin{array}{l}\text { Bolivia (1988), Colombia (1988), Ecuador (1988), Peru (1988), } \\
\text { Venezuela (1988) }\end{array}$ \\
\hline Australia - New Zealand (ANZCERTA) & FTA & Australia (1983), New Zealand (1983) \\
\hline $\begin{array}{l}\text { Association of Southeast Asian Nations } \\
\text { Free Trade Area }\end{array}$ & FTA & $\begin{array}{l}\text { Brunei (1992), Cambodia (1999), Indonesia (1992), Lao (1997), } \\
\text { Malaysia (1992), Myanmar (1997), Philippines (1992), Singapore } \\
\text { (1992), Thailand (1992), Vietnam (1995) }\end{array}$ \\
\hline $\begin{array}{l}\text { Central American Common Market } \\
\text { (CACM) }\end{array}$ & $\mathrm{CU}$ & $\begin{array}{l}\text { Costa Rica }(1964 \sim 1974 \text { / 1993), El Salvador (1961 1974 / 1993), } \\
\text { Guatemala }(1961 \sim 1974 \text { / 1993), Honduras }(1962 \sim 1974 / 1993) \text {, } \\
\text { Nicaragua }(1961 \sim 1974 \text { / 1993) }\end{array}$ \\
\hline $\begin{array}{l}\text { Dominican Republic - Central America } \\
\text { Free Trade Agreement (CAFTA-DR) }\end{array}$ & FTA & $\begin{array}{l}\text { Costa Rica (2009), Dominican Republic (2007), El Salvador (2006), } \\
\text { Guatemala (2006), Honduras (2006), Nicaragua (2006), United States } \\
\text { (2006) }\end{array}$ \\
\hline $\begin{array}{l}\text { Caribbean Community and Common } \\
\text { Market (CARICOM) }\end{array}$ & $\mathrm{CU}$ & $\begin{array}{l}\text { Bahamas (1983), Barbados (1973), Belize (1974), Dominica (1974), } \\
\text { Grenada (1974), Guyana (1973), Jamaica (1973), Haiti (2006), St. } \\
\text { Kitts and Nevis (1974), St. Lucia (1974), St. Vincent and the } \\
\text { Grenadines (1974), Suriname (1995), Trinidad and Tobago (1973) }\end{array}$ \\
\hline $\begin{array}{l}\text { Economic and Monetary Community of } \\
\text { Central Africa (CEMAC) }\end{array}$ & $\mathrm{CU}$ & $\begin{array}{l}\text { Central African Republic (1999), Cameroon (1999), Congo Rep. } \\
\text { (1999), Gabon (1999), Equatorial Guinea (1999), Chad (1999) }\end{array}$ \\
\hline $\begin{array}{l}\text { Commonwealth of Independent States } \\
\text { (CIS) }\end{array}$ & FTA & $\begin{array}{l}\text { Armenia (1995), Azerbaijan (1997), Belarus (1995), Georgia (1995), } \\
\text { Kazakhstan (1995), Russian Federation (1995), Tajikistan (1997), } \\
\text { Ukraine (1995), Uzbekistan (1995) }\end{array}$ \\
\hline $\begin{array}{l}\text { Common Market for Eastern and } \\
\text { Southern Africa (COMESA) }\end{array}$ & $\mathrm{CU}$ & $\begin{array}{l}\text { Burundi (1995), Comoros (1995), Djibouti (1995), Egypt (1999), } \\
\text { Ethiopia (1995), Kenya (1995), Madagascar (1995), Malawi (1995), } \\
\text { Mauritius (1995), Rwanda (1995), Seychelles (2009), Sudan (1995), } \\
\text { Tanzania (1995), Uganda (1995), Zambia (1995), Zimbabwe (1995) }\end{array}$ \\
\hline East African Community (EAC) & $\mathrm{CU}$ & $\begin{array}{l}\text { Burundi (2007), Kenya (2000), Rwanda (2007), Tanzania (2000), } \\
\text { Uganda (2000) }\end{array}$ \\
\hline $\begin{array}{l}\text { European Free Trade Association } \\
\text { (EFTA) }\end{array}$ & FTA & $\begin{array}{l}\text { Austria (1960 1995), Denmark (1960 1973), Finland (1986 1995), } \\
\text { Iceland (1970), Norway (1960), Portugal (1960 1986), Sweden } \\
(1960 \sim 1995) \text {, Switzerland (1960), United Kingdom (1960 1973) }\end{array}$ \\
\hline European Union & $\mathrm{CU}$ & $\begin{array}{l}\text { Austria (1995), Belgium-Luxembourg (1958), Bulgaria (2007), Cyprus } \\
\text { (2004), Czech Republic (2004), Denmark (1973), Estonia (2004), } \\
\text { Finland (1995), France (1957), Germany (1957), Greece (1981), } \\
\text { Hungary (2004), Ireland (1973), Italy (1957), Latvia (2004), Lithuania } \\
\text { (2004), Malta (2004), Netherlands (1957), Poland (2004), Portugal } \\
\text { (1986), Romania (2007), Slovakia (2004), Slovenia (2004), Spain } \\
\text { (1986), Sweden (1995), United Kingdom (1973) }\end{array}$ \\
\hline Southern Common Market (Mercosur) & $\mathrm{CU}$ & Argentina (1992), Brazil (1992), Paraguay (1992), Uruguay (1992) \\
\hline $\begin{array}{l}\text { North American Free Trade Agreement } \\
\text { (NAFTA) }\end{array}$ & FTA & Canada (1994), Mexico (1994), United States (1994) \\
\hline Pan-Arab Free Trade Area (PAFTA) & FTA & $\begin{array}{l}\text { Bahrain (1998), Egypt (1998), Jordan (1998), Kuwait (1998), Lebanon } \\
\text { (1998), Morocco (1998), Oman (1998), Qatar (1998), Saudi Arabia } \\
\text { (1998), Sudan (1998), Tunisia (1998), United Arab Emirates (1998) }\end{array}$ \\
\hline $\begin{array}{l}\text { Southern African Development } \\
\text { Community (SADC) }\end{array}$ & FTA & $\begin{array}{l}\text { Madagascar (2001), Malawi (2001), Mauritius (2001), Mozambique } \\
\text { (2001), South Africa (2001), Tanzania (2001), Zambia (2001), } \\
\text { Zimbabwe (2001) }\end{array}$ \\
\hline
\end{tabular}




\section{Appendix 2. Continued}

\begin{tabular}{lll}
\hline Trade agreement & Type & \multicolumn{1}{c}{ Member countries } \\
\hline $\begin{array}{l}\text { South Asian Free Trade Agreement } \\
\text { (SAFTA) }\end{array}$ & FTA & $\begin{array}{l}\text { Bangladesh (2006), India (2006), Nepal (2006), Pakistan (2006), Sri } \\
\text { Lanka (2006) }\end{array}$ \\
West African Economic and Monetary & CU $\quad \begin{array}{l}\text { Benin (2000), Burkina Faso (2000), Côte d'Ivoire (2000), } \\
\text { Guinea-Bissau (2000), Mali (2000), Niger (2000), Senegal (2000), } \\
\text { Union (WAEMU) }\end{array}$ \\
& & Togo (2000)
\end{tabular}

(Notes) $\mathrm{CU}=$ Customs Union; FTA $=$ Free Trade Agreement. Year in parentheses indicates the date of entry into force of an RTA or the date when new member country joins the RTA.

\section{Appendix 3. Geographic area of RTAs included in the estimation}

$$
\begin{aligned}
& \text { ANDEAN } \\
& \text { ASEAN } \\
& \text { ANZCERTA } \\
& \text { CIS } \\
& \text { EU } \\
& \text { EFTA } \\
& \text { NAFTA } \\
& \text { PAFTA } \\
& \text { SAFTA } \\
& \text { MERCOSUR } \\
& \text { CACM } \\
& \text { CARICOM } \\
& \text { WAEMU } \\
& \text { EAC } \\
& \text { CEMAC } \\
& \text { SADC }
\end{aligned}
$$

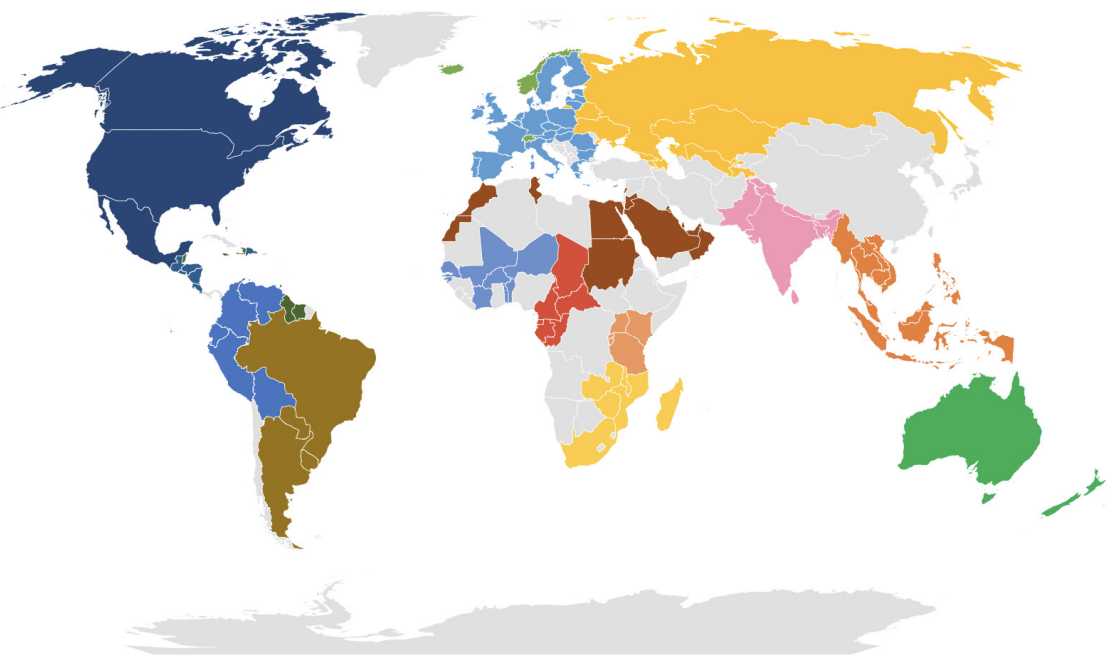

(Source) Author. 


\section{Appendix 4. Summary statistics}

\begin{tabular}{|c|c|c|c|c|c|}
\hline \multirow{2}{*}{ VARIABLES } & (1) & (2) & (3) & (4) & (5) \\
\hline & $\mathrm{N}$ & Mean & Standard Deviation & Min & Max \\
\hline$X_{i j t}$ & $1,377,473$ & $1.950 \times 10^{8}$ & $2.939 \times 10^{9}$ & 0 & $4.668 \times 10^{11}$ \\
\hline$G D P_{i t}$ & $1,262,937$ & $1.667 \times 10^{11}$ & $8.225 \times 10^{11}$ & $11,592,048$ & $1.742 \times 10^{13}$ \\
\hline$G D P_{j t}$ & $1,262,937$ & $1.667 \times 10^{11}$ & $8.225 \times 10^{11}$ & $11,592,048$ & $1.742 \times 10^{13}$ \\
\hline CONTIG $_{i j}$ & $1,399,200$ & 0.018 & 0.132 & 0 & 1 \\
\hline $\ln \left(G D P_{i t}\right)$ & $1,262,937$ & 22.931 & 2.497 & 16.266 & 30.489 \\
\hline $\ln \left(G D P_{j i}\right)$ & $1,262,938$ & 22.931 & 2.497 & 16.266 & 30.489 \\
\hline$L A N G_{i j}$ & $1,399,200$ & 0.152 & 0.359 & 0 & 1 \\
\hline$D I S T_{i j}$ & $1,399,201$ & $7,788.990$ & $4,446.031$ & 60.771 & $19,650.127$ \\
\hline $\ln \left(D I S T_{i j}\right)$ & $1,399,202$ & 8.736 & 0.766 & 4.107 & 9.886 \\
\hline$A N D E A N \_$Intra $a_{i j t}$ & $1,399,203$ & 0.000 & 0.020 & 0 & 1 \\
\hline ANZCERTA_Intra ${ }_{i j t}$ & $1,399,205$ & 0.000 & 0.007 & 0 & 1 \\
\hline$A S E A N \_$Intra ${ }_{i j t}$ & $1,399,204$ & 0.001 & 0.035 & 0 & 1 \\
\hline CACM_Intra ${ }_{i j t}$ & $1,399,220$ & 0.000 & 0.022 & 0 & 1 \\
\hline CAFTA-DR_Intra $a_{i j t}$ & $1,399,208$ & 0.000 & 0.015 & 0 & 1 \\
\hline CARICOM_Intra & $1,399,219$ & 0.004 & 0.060 & 0 & 1 \\
\hline CEMAC_Intra $a_{i j t}$ & $1,399,217$ & 0.000 & 0.019 & 0 & 1 \\
\hline CIS_Intra $a_{i j t}$ & $1,399,207$ & 0.001 & 0.031 & 0 & 1 \\
\hline COMESA_Intra $a_{i j t}$ & $1,399,206$ & 0.003 & 0.055 & 0 & 1 \\
\hline$E A C \_$Intra ${ }_{i j t}$ & $1,399,218$ & 0.000 & 0.012 & 0 & 1 \\
\hline EFTA_Intra & $1,399,210$ & 0.001 & 0.032 & 0 & 1 \\
\hline$E U_{-}$Intra $_{i j t}$ & $1,399,209$ & 0.009 & 0.092 & 0 & 1 \\
\hline MERCOSUR_Intra $a_{i j t}$ & $1,399,214$ & 0.000 & 0.014 & 0 & 1 \\
\hline NAFTA_Intra $a_{i j t}$ & $1,399,211$ & 0.000 & 0.009 & 0 & 1 \\
\hline PAFTA_Intra $a_{i j t}$ & $1,399,212$ & 0.002 & 0.040 & 0 & 1 \\
\hline SADC_Intra ${ }_{i j t}$ & $1,399,216$ & 0.001 & 0.024 & 0 & 1 \\
\hline SAFTA_Intra $a_{i j t}$ & $1,399,213$ & 0.000 & 0.011 & 0 & 1 \\
\hline WAEMU_Intra ${ }_{i j t}$ & $1,399,215$ & 0.001 & 0.024 & 0 & 1 \\
\hline
\end{tabular}

(Note) For the sake of brevity, we do not report here the RTA variables for extra-bloc trade. (Source) Author's calculations. 
276 Journal of Economic Integration Vol. 34, No. 2

\section{Appendix 5. Effects of RTAs on extra-bloc trade based on different intervals panel data}

\begin{tabular}{|c|c|c|c|}
\hline \multirow{2}{*}{ Specifications } & \multicolumn{3}{|c|}{ PPML } \\
\hline & & $X_{i j t}$ & \\
\hline \multirow{2}{*}{ Variables } & Consecutive years & 3-year intervals & 4-year intervals \\
\hline & (1) & (2) & (3) \\
\hline \multirow[t]{2}{*}{$A N D E A N \_$Intra } & $0.714 * * *$ & $0.771^{* * *}$ & $0.800^{* * *}$ \\
\hline & $(0.133)$ & $(0.138)$ & $(0.179)$ \\
\hline \multirow[t]{2}{*}{$A N D E A N \_X$} & -0.161 & -0.063 & -0.161 \\
\hline & $(0.130)$ & $(0.132)$ & $(0.137)$ \\
\hline \multirow[t]{2}{*}{$A N D E A N \_M$} & $-0.158^{*}$ & $-0.187^{*}$ & -0.137 \\
\hline & $(0.095)$ & $(0.104)$ & $(0.099)$ \\
\hline \multirow[t]{2}{*}{ ANZCERTA_Intra } & 0.039 & 0.050 & 0.052 \\
\hline & $(0.189)$ & $(0.197)$ & $(0.182)$ \\
\hline \multirow[t]{2}{*}{ ANZCERTA_X } & $-0.294 * * *$ & $-0.248^{* *}$ & $-0.345 * * *$ \\
\hline & $(0.108)$ & $(0.114)$ & $(0.110)$ \\
\hline \multirow[t]{2}{*}{ ANZCERTA_M } & -0.068 & -0.053 & -0.034 \\
\hline & $(0.119)$ & $(0.121)$ & $(0.122)$ \\
\hline \multirow[t]{2}{*}{ ASEAN_Intra } & 0.012 & 0.070 & 0.152 \\
\hline & $(0.176)$ & $(0.191)$ & $(0.201)$ \\
\hline \multirow[t]{2}{*}{$A S E A N \_X$} & 0.137 & 0.172 & 0.175 \\
\hline & $(0.110)$ & $(0.116)$ & $(0.124)$ \\
\hline \multirow[t]{2}{*}{$A S E A N \_M$} & 0.093 & 0.104 & $0.196^{* *}$ \\
\hline & $(0.075)$ & $(0.078)$ & $(0.079)$ \\
\hline \multirow[t]{2}{*}{ CACM_Intra } & 0.056 & 0.020 & 0.015 \\
\hline & $(0.139)$ & $(0.150)$ & $(0.142)$ \\
\hline \multirow[t]{2}{*}{$C A C M \_X$} & $0.216^{*}$ & $0.209^{*}$ & $0.242^{* *}$ \\
\hline & $(0.115)$ & $(0.118)$ & $(0.115)$ \\
\hline \multirow[t]{2}{*}{$C A C M \_M$} & $0.372 * * *$ & $0.373^{* * *}$ & $0.369 * * *$ \\
\hline & $(0.081)$ & $(0.087)$ & $(0.074)$ \\
\hline \multirow[t]{2}{*}{ CAFTADR_Intra } & -0.001 & 0.024 & 0.010 \\
\hline & $(0.109)$ & $(0.101)$ & $(0.124)$ \\
\hline \multirow[t]{2}{*}{ CAFTADR_X } & -0.083 & -0.031 & -0.063 \\
\hline & $(0.065)$ & $(0.070)$ & $(0.066)$ \\
\hline \multirow[t]{2}{*}{ CAFTADR_M } & -0.099 & $-0.111^{*}$ & $-0.107 *$ \\
\hline & $(0.066)$ & $(0.062)$ & $(0.062)$ \\
\hline \multirow[t]{2}{*}{ CARICOM_Intra } & -0.711 & -0.681 & -0.629 \\
\hline & $(0.438)$ & $(0.480)$ & $(0.401)$ \\
\hline \multirow[t]{2}{*}{ CARICOM_X } & $-1.279 * * *$ & $-1.290 * * *$ & $-1.210 * * *$ \\
\hline & $(0.441)$ & $(0.466)$ & $(0.397)$ \\
\hline
\end{tabular}




\section{Appendix 5. Continued}

\begin{tabular}{|c|c|c|c|}
\hline \multirow{2}{*}{ Specifications } & \multicolumn{3}{|c|}{ PPML } \\
\hline & \multicolumn{3}{|c|}{$X_{i j t}$} \\
\hline \multirow{2}{*}{ Variables } & Consecutive years & 3-year intervals & 4-year intervals \\
\hline & $(1)$ & $(2)$ & (3) \\
\hline \multirow[t]{2}{*}{ CARICOM_M } & $-0.448^{* *}$ & $-0.428^{*}$ & $-0.426^{*}$ \\
\hline & $(0.228)$ & $(0.230)$ & $(0.235)$ \\
\hline \multirow[t]{2}{*}{ CEMAC_Intra } & -0.373 & -0.397 & -0.367 \\
\hline & $(0.262)$ & $(0.260)$ & $(0.279)$ \\
\hline \multirow[t]{2}{*}{ CEMAC_X } & -0.133 & -0.140 & -0.073 \\
\hline & $(0.143)$ & $(0.148)$ & $(0.153)$ \\
\hline \multirow[t]{2}{*}{ CEMAC_M } & -0.122 & -0.148 & -0.181 \\
\hline & $(0.111)$ & $(0.121)$ & $(0.124)$ \\
\hline \multirow[t]{2}{*}{ CIS_Intra } & $1.809 * * *$ & $2.829 * * *$ & $2.220 * * *$ \\
\hline & $(0.277)$ & $(0.508)$ & $(0.612)$ \\
\hline \multirow[t]{2}{*}{ CIS_X } & $1.418 * * *$ & $1.451 * * *$ & $1.628 * * *$ \\
\hline & $(0.130)$ & $(0.134)$ & $(0.144)$ \\
\hline \multirow[t]{2}{*}{$C I S \_M$} & $0.695^{* * *}$ & $0.681 * * *$ & $0.872 * * *$ \\
\hline & $(0.144)$ & $(0.141)$ & $(0.156)$ \\
\hline \multirow[t]{2}{*}{ COMESA_Intra } & $0.243^{*}$ & 0.184 & $0.262 *$ \\
\hline & $(0.126)$ & $(0.138)$ & $(0.145)$ \\
\hline \multirow[t]{2}{*}{ COMESA_X } & $-0.237^{* *}$ & $-0.253^{* *}$ & $-0.275^{* *}$ \\
\hline & $(0.102)$ & $(0.111)$ & $(0.108)$ \\
\hline \multirow[t]{2}{*}{ COMESA_M } & $-0.279 * * *$ & $-0.294 * * *$ & $-0.274 * * *$ \\
\hline & $(0.073)$ & $(0.077)$ & $(0.081)$ \\
\hline \multirow[t]{2}{*}{ EAC_Intra } & $-0.361 * *$ & $-0.324 *$ & $-0.382 * *$ \\
\hline & $(0.156)$ & $(0.168)$ & $(0.168)$ \\
\hline \multirow[t]{2}{*}{$E A C \_X$} & $-0.610 * * *$ & $-0.558 * * *$ & $-0.653 * * *$ \\
\hline & $(0.112)$ & $(0.117)$ & $(0.119)$ \\
\hline \multirow[t]{2}{*}{$E A C_{-} M$} & -0.020 & 0.041 & 0.007 \\
\hline & $(0.113)$ & $(0.119)$ & $(0.122)$ \\
\hline \multirow[t]{2}{*}{ EFTA_Intra } & $0.598^{* * *}$ & $0.766^{* * *}$ & $0.694 * * *$ \\
\hline & $(0.100)$ & $(0.111)$ & $(0.115)$ \\
\hline \multirow[t]{2}{*}{ EFTA_X } & $0.307^{* * *}$ & $0.402 * * *$ & $0.358^{* * *}$ \\
\hline & $(0.056)$ & $(0.066)$ & $(0.070)$ \\
\hline \multirow[t]{2}{*}{ EFTA_M } & $0.276^{* * *}$ & $0.376^{* * *}$ & $0.385^{* * *}$ \\
\hline & $(0.056)$ & $(0.064)$ & $(0.067)$ \\
\hline \multirow[t]{2}{*}{ EU_Intra } & $0.567^{* * *}$ & $0.652 * * *$ & $0.633^{* * *}$ \\
\hline & $(0.063)$ & $(0.072)$ & $(0.077)$ \\
\hline \multirow[t]{2}{*}{$E U_{-} X$} & $0.091^{*}$ & $0.126^{* *}$ & 0.080 \\
\hline & $(0.055)$ & $(0.061)$ & $(0.066)$ \\
\hline
\end{tabular}


278 Journal of Economic Integration Vol. 34, No. 2

\section{Appendix 5. Continued}

\begin{tabular}{|c|c|c|c|}
\hline \multirow{2}{*}{ Specifications } & \multicolumn{3}{|c|}{ PPML } \\
\hline & \multicolumn{3}{|c|}{$X_{i j t}$} \\
\hline \multirow{2}{*}{ Variables } & Consecutive years & 3-year intervals & 4-year intervals \\
\hline & $(1)$ & (2) & (3) \\
\hline \multirow[t]{2}{*}{$E U_{-} M$} & -0.045 & -0.013 & -0.007 \\
\hline & $(0.054)$ & $(0.060)$ & $(0.063)$ \\
\hline \multirow[t]{2}{*}{ MERCOSUR_Intra } & $0.605^{* * *}$ & $0.595 * * *$ & $0.530 * * *$ \\
\hline & $(0.145)$ & $(0.152)$ & $(0.123)$ \\
\hline \multirow[t]{2}{*}{ MERCOSUR_X } & $-0.134 *$ & $-0.136^{*}$ & $-0.196^{* *}$ \\
\hline & $(0.073)$ & $(0.077)$ & $(0.081)$ \\
\hline \multirow[t]{2}{*}{ MERCOSUR_M } & 0.115 & 0.093 & 0.043 \\
\hline & $(0.088)$ & $(0.093)$ & $(0.087)$ \\
\hline \multirow[t]{2}{*}{ NAFTA_Intra } & $0.290 * *$ & $0.275^{* *}$ & $0.281 * *$ \\
\hline & $(0.114)$ & $(0.132)$ & $(0.119)$ \\
\hline \multirow[t]{2}{*}{$N A F T A \_X$} & $-0.195 * * *$ & $-0.201 * * *$ & $-0.202 * * *$ \\
\hline & $(0.042)$ & $(0.043)$ & $(0.042)$ \\
\hline \multirow[t]{2}{*}{$N A F T A \_M$} & 0.094 & 0.080 & 0.105 \\
\hline & $(0.099)$ & $(0.097)$ & $(0.100)$ \\
\hline \multirow[t]{2}{*}{ PAFTA_Intra } & -0.145 & -0.141 & -0.139 \\
\hline & $(0.158)$ & $(0.170)$ & $(0.164)$ \\
\hline \multirow[t]{2}{*}{ PAFTA_X } & $-0.164^{* *}$ & $-0.137^{*}$ & $-0.128^{*}$ \\
\hline & $(0.075)$ & $(0.076)$ & $(0.075)$ \\
\hline \multirow[t]{2}{*}{ PAFTA_M } & -0.084 & -0.057 & -0.073 \\
\hline & $(0.071)$ & $(0.075)$ & $(0.076)$ \\
\hline \multirow[t]{2}{*}{ SADC_Intra } & $0.745^{* * *}$ & $0.764 * * *$ & $0.724 * * *$ \\
\hline & $(0.135)$ & $(0.151)$ & $(0.167)$ \\
\hline \multirow[t]{2}{*}{$S A D C_{-} X$} & 0.174 & $0.225^{*}$ & 0.212 \\
\hline & $(0.122)$ & $(0.124)$ & $(0.130)$ \\
\hline \multirow[t]{2}{*}{$S A D C \_M$} & $0.182 *$ & $0.177 *$ & $0.190^{* *}$ \\
\hline & $(0.102)$ & $(0.103)$ & $(0.097)$ \\
\hline \multirow[t]{2}{*}{ SAFTA_Intra } & $0.310^{* * *}$ & $0.333^{* * *}$ & $0.328^{* * *}$ \\
\hline & $(0.110)$ & $(0.116)$ & $(0.101)$ \\
\hline \multirow[t]{2}{*}{$S A F T A \_X$} & $0.369^{* * *}$ & $0.397 * * *$ & $0.401 * * *$ \\
\hline & $(0.074)$ & $(0.073)$ & $(0.075)$ \\
\hline \multirow[t]{2}{*}{$S A F T A \_M$} & $0.475^{* * *}$ & $0.463^{* * *}$ & $0.532 * * *$ \\
\hline & $(0.094)$ & $(0.094)$ & $(0.096)$ \\
\hline \multirow[t]{2}{*}{ WAEMU_Intra } & 0.067 & 0.013 & 0.127 \\
\hline & $(0.144)$ & $(0.147)$ & $(0.135)$ \\
\hline \multirow[t]{2}{*}{ WAEMU_X } & $-0.330 * * *$ & $-0.322 * * *$ & $-0.373 * * *$ \\
\hline & $(0.084)$ & $(0.086)$ & $(0.084)$ \\
\hline
\end{tabular}




\section{Appendix 5. Continued}

\begin{tabular}{lccc}
\hline \multirow{2}{*}{ Specifications } & \multicolumn{3}{c}{ PPML } \\
\cline { 2 - 4 } Variables & Consecutive years & 3-year intervals & 4-year intervals \\
\cline { 2 - 4 } & $(1)$ & $(2)$ & $(3)$ \\
\hline WAEMU_M & $-0.121^{*}$ & -0.094 & -0.129 \\
& $(0.073)$ & $(0.075)$ & $(0.088)$ \\
$\ln \left(G D P_{i t}\right)$ & $0.744^{* * *}$ & $0.737^{* * *}$ & $0.737^{* * *}$ \\
& $(0.038)$ & $(0.038)$ & $(0.039)$ \\
$\ln \left(G D P_{j i t}\right)$ & $0.667^{* * *}$ & $0.651^{* * *}$ & $0.653^{* * *}$ \\
& $(0.062)$ & $(0.063)$ & $(0.061)$ \\
Observations & $1,039,417$ & 347,537 & 248,524 \\
Country pairs & 22,847 & 22,031 & 21,618 \\
Country-pair FEs & Yes & Yes & Yes \\
Year FEs & Yes & Yes & Yes \\
\hline
\end{tabular}

(Notes) This table reports estimates of the effects of trading blocs on intra-bloc trade and extra-bloc trade. All estimates are obtained by using the PPML estimator with country-pair and year fixed effects. The estimates of the fixed effects are omitted for brevity. Columns (1), (2) and (3) employ the data with consecutive years, 3-year intervals and 4-year intervals, respectively. Standard errors are reported in parentheses and clustered by country pair. *, $* *$ and $* * *$ denote significance at the level of $10 \%, 5 \%$ and $1 \%$, respectively. 